\title{
Discovery of a Novel Series of Tankyrase Inhibitors by a Hybridization Approach
}

\author{
Upendra Rao Anumala, ${ }^{\dagger}$ Jo Waaler, $^{\S, \|}$ Yves Nkizinkiko, ${ }^{\perp}$ Alexander Ignatev, ${ }^{\perp}$ Katina Lazarow, ${ }^{\dagger}$
} Peter Lindemann, ${ }^{\dagger}$ Petter Angell Olsen, ${ }^{\S}, \|$ Sudarshan Murthy, ${ }^{\perp}$ Ezeogo Obaji, ${ }^{\perp}$ Alexander G. Majouga,

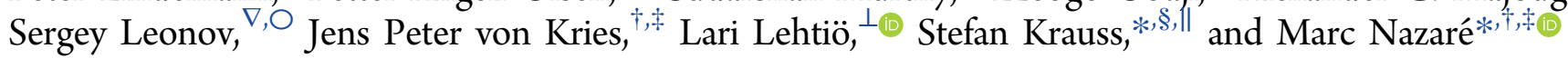

${ }^{\dagger}$ Leibniz-Forschungsinstitut für Molekulare Pharmakologie (FMP), Campus Berlin-Buch, 13125 Berlin, Germany

${ }^{\ddagger}$ Berlin Institute of Health (BIH), Anna-Louisa-Karsch-Strasse 2, 10178 Berlin, Germany

${ }^{\S}$ Unit for Cell Signaling, Institute of Medical Microbiology, Oslo University Hospital, Gaustadalleen 34, 0372 Oslo, Norway

${ }^{\|}$Hybrid Technology Hub, Centre of Excellence, Institute of Basic Medical Sciences, University of Oslo, 0372 Oslo, Norway

${ }^{\perp}$ Faculty of Biochemistry and Molecular Medicine, Biocenter Oulu, University of Oulu, P.O. Box 5400, 90014 Oulu, Finland

\# Department of Chemistry, Moscow State University, Leninskie Gory 1/3, Moscow 119991, Russia

${ }^{\nabla}$ National University of Science and Technology MISiS, Leninsky Avenue 4, Moscow 119049, Russia

${ }^{\circ}$ Moscow Institute of Physics and Technology (State University), Institutskiy Lane 9, 141700 Dolgoprudny, Russia

\section{Supporting Information}

ABSTRACT: A structure-guided hybridization approach using two privileged substructures gave instant access to a new series of tankyrase inhibitors. The identified inhibitor 16 displays high target affinity on tankyrase 1 and 2 with biochemical and cellular $\mathrm{IC}_{50}$ values of $29 \mathrm{nM}, 6.3 \mathrm{nM}$ and 19 $\mathrm{nM}$, respectively, and high selectivity toward other poly (ADPribose) polymerase enzymes. The identified inhibitor shows a favorable in vitro ADME profile as well as good oral bioavailability in mice, rats, and dogs. Critical for the approach was the utilization of an appropriate linker between 1,2,4triazole and benzimidazolone moieties, whereby a cyclobutyl linker displayed superior affinity compared to a cyclohexane and phenyl linker.
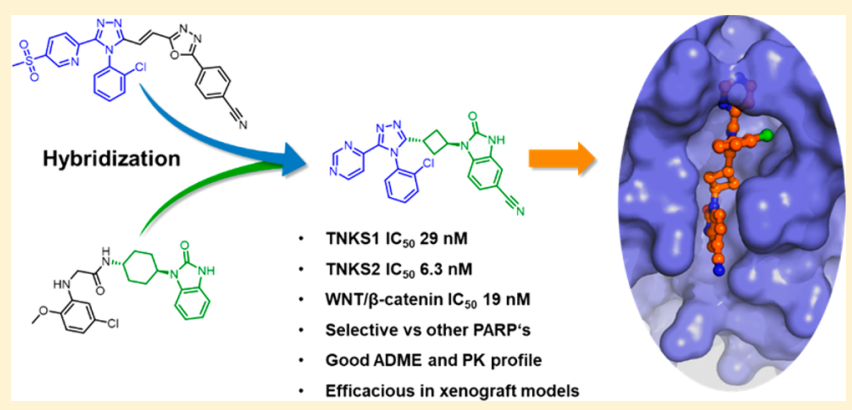

\section{INTRODUCTION}

Catalytic modification of proteins using the redox metabolite nicotinamide adenine dinucleotide $\left(\mathrm{NAD}^{+}\right)$as a substrate to successively add $\mathrm{ADP}$-ribose moieties onto the target protein is known as PARsylation. ${ }^{1}$ In 1960s, this posttranslational protein modification was reported with the identification of PARP1 and its role in DNA repair. ${ }^{2-4}$ There are two classes of PARP enzymes: mono(ADP-ribosyl)ating and (oligo-)poly(ADPribosyl)ating proteins. ${ }^{5,6}$ The poly (ADP-ribose) polymerases tankyrase 1 and tankyrase 2 (TNKS1, PARP5a and TNKS2, PARP5b) share almost $82 \%$ sequence identity and show predominantly cytoplasmic differential expression in a variety of tissues. ${ }^{7}$ Both tankyrase paralogs have three functional segments: the carboxy terminal catalytic ARTD domain (ADP-ribosyltransferase with diphtheria toxin homology), five ankyrin domains involved in protein/protein interactions with target proteins such as AXIN, NuMA, TRF1, GRB, and IRAP ${ }^{8}$ and a sterile $\alpha$ motif (SAM) domain that is involved in tankyrase polymerization and supports the catalytic activity of the PARP domain. ${ }^{9}$ The catalytic ARTD domains of both tankyrases show high similarity with $89 \%$ sequence identity.
Tankyrases can control, in a context dependent manner, several cellular pathways including the $\mathrm{WNT} / \beta$-catenin signaling pathway that executes key functions in embryonic development, stem cell biology, cell fate specification, energy metabolism, and cell migration. Other roles of tankyrases comprise the involvement in, for example, mitosis and cherubism. ${ }^{6,10-14}$ Tankyrase inhibition may have therapeutic potential in several diseases like selected cancers such as colorectal carcinoma and non-small-cell lung cancer as well as in fibrotic diseases and herpes simplex virus (HSV) infections. $^{15-17}$

Several tankyrase inhibitors emerging from high throughput screening or chemical optimization efforts have recently been reported, and inhibitor binding modes in the active site have been effectively elucidated by X-ray crystallography and complemented by in silico docking studies. ${ }^{13,18-28}$ Two distinct binding sites, the nicotinamide and the adenosine subpocket, have been described to accommodate small molecule ligands. Compound 1 (XAV939), binding to the nicotinamide

Received: June 29, 2017

Published: November 20, 2017 
A)<smiles>CC(=O)OCc1ccc(-c2nc3c(c(=O)[nH]2)CSCC3)cc1</smiles>

1 (XAV939)<smiles>CC(C)(C)c1ccc(-c2nc3ccccc3c(=O)[nH]2)cc1</smiles><smiles>CS(=O)(=O)c1ccccc1N1CCN(c2nc3c(c(=O)[nH]2)CSCC3)CC1</smiles><smiles>CC(C)(C)c1ccc(C(=O)Nc2nnc3n2CCS3)cc1</smiles>

B)<smiles>COc1ccc(-n2c(SCc3nc(-c4ccc(C)cc4)no3)nnc2-c2ccncc2)cc1</smiles>

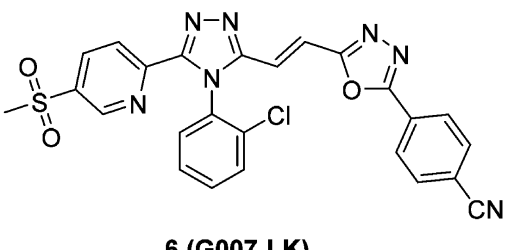<smiles>COc1ccc(C(=O)Nc2ccc(C(=O)N(c3ccncn3)c3ccccc3Cl)cc2)cc1</smiles>

7 (OD332)<smiles>COc1ccc(Cl)cc1NCC(=O)N[C@H]1CC[C@H](n2c(=O)[nH]c3ccccc32)CC1</smiles>

8

C)<smiles>COc1ccccc1NC(=O)c1ccc(NC(=O)CCc2nc3ccccc3c(=O)[nH]2)cc1</smiles><smiles>[R]c1ccnc2c(NC(=O)c3ccc(N4C(=O)C5C6C=CC(C6)C5C4=O)cc3)cccc12</smiles>

$R=H, 9 a$ (IWR1) $\mathrm{R}=\mathrm{Me}, 9 \mathrm{~b}$ (IWR2)<smiles>CC1(C)OC(=O)N(C2CCC(c3cnc(N)c(-c4ncccn4)c3)CC2)[C@H]1c1ccccc1</smiles>

10

Figure 1. Examples of chemical structures of known tankyrase inhibitors: (A) inhibitors addressing the nicotinamide pocket $\left(\mathbf{1},{ }^{13} \mathbf{2},{ }^{23} \mathbf{3},{ }^{12} \mathbf{4}^{21}\right)$; $(\mathrm{B})$ inhibitors addressing the adenosine pocket $\left(5,{ }^{18} 6,{ }^{18} 7,,^{24} 8,{ }^{20} 9,{ }^{20} 10^{19}\right) ;(C)$ dual inhibitors addressing the adenosine and nicotinamide pocket $\left(11,{ }^{26} 12,{ }^{22} 13^{27}\right)$.

subpocket, was the first reported tankyrase inhibitor that showed an impact on WNT/ $\beta$-catenin signaling by stabilizing AXIN and decreasing $\beta$-catenin levels. ${ }^{13}$ Due to the conservation of the nicotinamide subpocket throughout the entire PARP family, 1 and related inhibitors $2-4$ show variable selectivity toward the other members of the PARP family.

In contrast to the nicotinamide binding site, the architecture of the adenosine binding cavity is more varied between PARPs. Consequently, inhibitors addressing the adenosine subpocket of TNKS1/2 appear to be intrinsically more selective over the other members of the PARP family. Notably only tankyrase has been reported to be effectively inhibited by a compound that is solely binding to this subpocket. Recently, dual site tankyrase inhibitors that span both the nicotinamide and the adenosine binding site have been shown to be potent and tankyrase selective. $^{22,11,26-28}$ Examples of reported tankyrase inhibitors are given in Figure 1.

We previously reported the discovery of a 1,2,4-triazole based specific tankyrase inhibitor 5 (JW74) which culminated in the development of 6 (G007-LK) which inhibits TNKS1/2 in vitro and in vivo with high specificity. ${ }^{18}$ However, albeit being highly potent and selective and showing an excellent oral bioavailability in mice, 6 had poor PK in rats, hampering its further preclinical development. Here we report the design of a new class of tankyrase inhibitors based on a hybridization approach of privileged fragments from two distinct inhibitor series ${ }^{18} 6$ and 8 described by Bregman et al. ${ }^{20}$ We show that the lead compound of the series shows a further improved affinity and cellular activity, good solubility, good target specificity within the PARP family, low adverse inhibition in a kinase panel, good oral bioavailability in mouse, rat, and dog, as well as efficacy in mouse xenograft models.

\section{RESULTS AND DISCUSSION}

Design of the Hybrid Inhibitors. Our previous studies of the diaryl 1,2,4-triazole series yielded potent and selective tankyrase inhibitors. ${ }^{18,29}$ However, the lead compound $\mathbf{6}$ suffered from an extended, highly conjugated, aromatic system incorporating a vinylic bond in combination with the intrinsically high lipophilicity, a negligible low $\mathrm{Fsp}^{3}$ content and a critically high molecular weight for some derivatives. Collectively, this suggested that a further classical optimization with incremental structural changes may not solve these issues. We speculated that due to the resemblance of the $\mathrm{N}$ disubstituted glycine pharmacophore in 8 with a diaryl 1,2,4triazole, the distal benzimidazolone could be grafted on this 


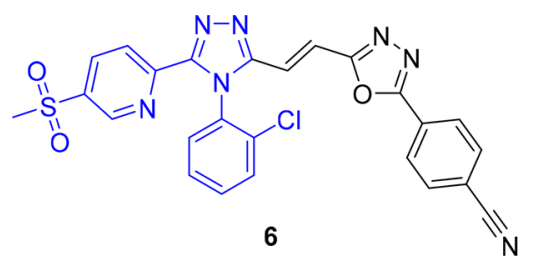<smiles>COc1ccc(Cl)cc1NCC(=O)N[C@H]1CC[C@H](n2c(=O)[nH]c3ccccc32)CC1</smiles>

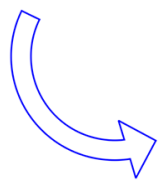<smiles>N#Cc1ccc2c(c1)[nH]c(=O)n2-c1ccc(-c2nnc(-c3ccncn3)n2-c2ccccc2Cl)cc1</smiles>

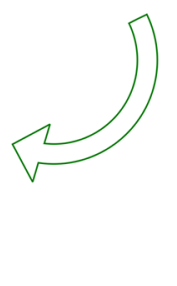<smiles>N#Cc1ccc2c(c1)[nH]c(=O)n2C1CCC(c2nnc(-c3ccncn3)n2-c2ccccc2Cl)CC1</smiles><smiles>N#Cc1ccc2c(c1)[nH]c(=O)n2C1CC(c2nnc(-c3ccncn3)n2-c2ccccc2Cl)C1</smiles>

Figure 2. Hybridization design strategy for the new tankyrase inhibitors 14-16.

scaffold with the appropriate spacer. Thus, we resorted to a hybridization approach by joining the diaryl substituted 1,2,4triazole and the benzimidazolone from the two inhibitors 6 and 8 (Figure 2). The available cocrystal structures of TNKS2-6 and TNKS1-8 analogs were used to guide the hybrid and linker design (Figure $3 a-c)$. In these crystal structures the hydrogen bonding pattern is conserved and importantly the atoms of the triazole and glycine moieties superpose well and the vinyl and cyclohexane linkers occupy the same space in the pocket (Figure 3c). An appropriate linker for the hybridization approach would thus enable us to preserve the overall binding mode and maintain distinct interaction anchor points of the merged fragments. Three different linkers were chosen to provide the appropriate distance and conformational adaptability within this new class of tankyrase inhibitors (Figure 2). Design was based on the parent compound crystal structures, and docking was used to check compatibility with the binding pocket. A phenyl linker group present in $\mathbf{1 4}$ has been used in many tankyrase inhibitors at this position (Figure 1, compounds $7,9,11$ ), while a saturated cyclohexyl in 15 is equidistant but provides more flexibility to the linker. A shorter and more rigid 1,3-trans substituted cyclobutyl (16) was designed as a novel linker in the hybrid compound (Figure 2).

Synthesis of the Designed Tankyrase Inhibitors. The phenyl derivative 14 was synthesized by coupling of pyrimidyl imidohydrazide derivative $\mathbf{2 0}$ with the benzimidazolone acid $\mathbf{2 2}$ in a key condensation step. The pyrimidyl imidohydrazide derivative 20 was obtained via activation of the amide as imidoyl cloride intermediate 19 and subsequent substitution with hydrazine hydrate. This building block 20 was then coupled with benzimidazolone acid 22 using EDCI and cyclized by dehydration in refluxing toluene to afford the phenyl triazole 14 (Scheme 1).

The cyclohexyl and cyclobutyl derivatives 15, 15a and 16, 16a were synthesized by analogous convergent routes (Scheme 2). Carbimidothioate building block 26 was prepared from $N$ (2-chlorophenyl)pyrimidine-4-carboxamide 24 by thionation with Lawesson's reagent to afford 25, and subsequent methylation with methyl tosylate in the presence of potassium tert-butoxide resulted in 26. The benzimidazolone ester intermediates $(\mathbf{3 0 a}-\mathbf{d})$ were constructed using a three-step sequence consisting of nucleophilic aromatic substitution, reduction, and cyclization. The nucleophilic aromatic substitution reaction of 4-fluoro-3-nitrobenzonitrile (28a), as well as for 1-fluoro-2-nitrobenzene (28b), with $\mathbf{2 7 a}, \mathbf{b}$ respectively, was followed by a hydrogenation under standard conditions in the presence of palladium on charcoal to afford the corresponding diamines. Treatment with triphosgene yielded the benzimidazolone ester derivatives $30 \mathrm{a}-\mathbf{d}$. These esters 30a-d were then converted into the hydrazide $31 \mathbf{a}-\mathbf{d}$ using hydrazine hydrate and were then condensed with the carbimidothioate 26 to afford the final triazole derivatives 15, $15 \mathrm{a}$ and 16, 16a. 


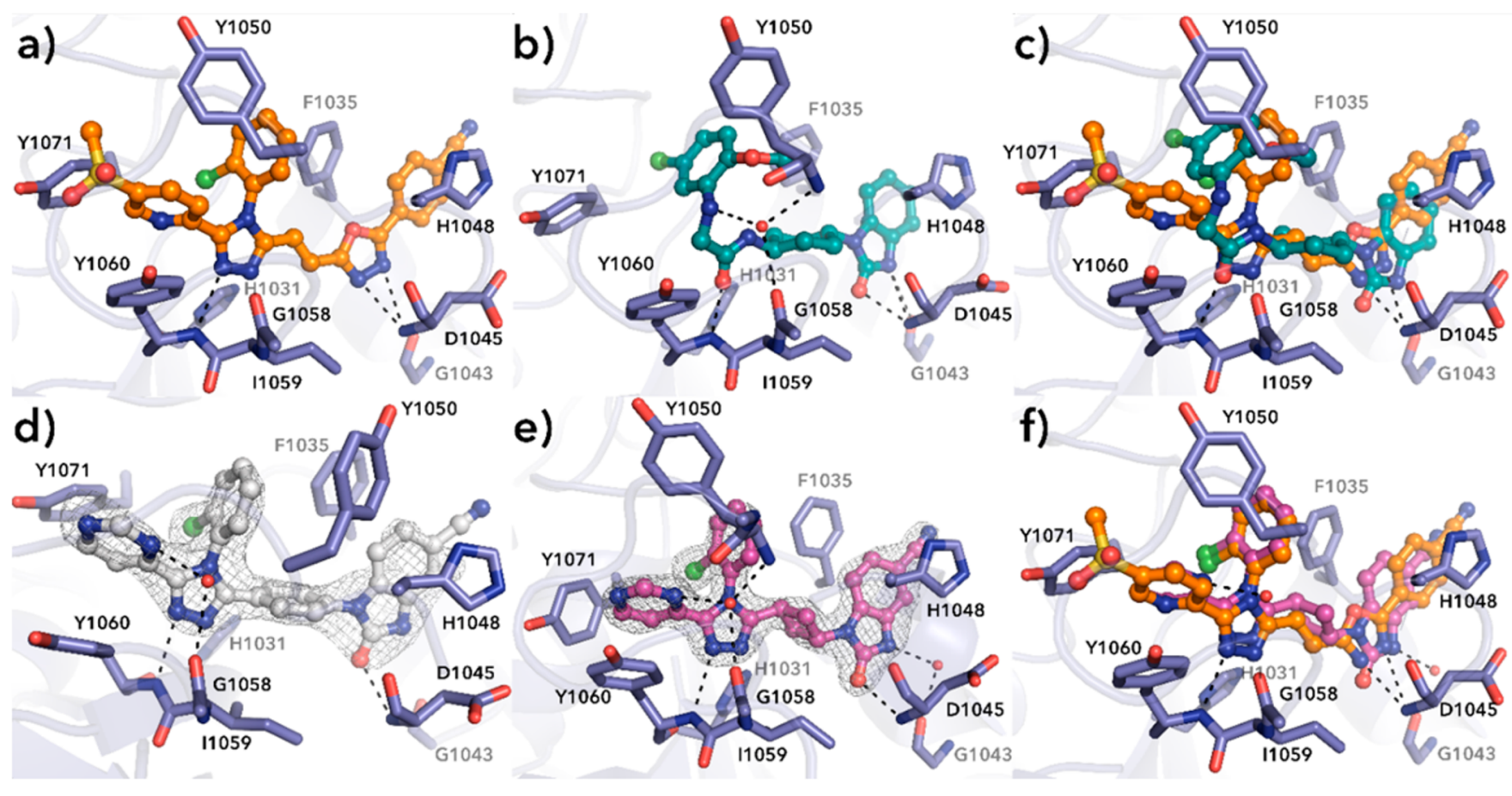

Figure 3. Cocrystal structures of TNKS1/2 and inhibitors. (a) Binding mode of 6 in TNKS2 catalytic domain (PDB code 4HYF). (b) Binding mode of $\mathbf{8}$ in TNKS1 catalytic domain (PDB code 4K4E). (c) Superposition of $\mathbf{6}$ and $\mathbf{8}$ cocrystal structures. Only TNKS2 protein is shown for clarity. (d) Cocrystal structure of 14 with TNKS2 (PDB code 5NSP). $\sigma_{\mathrm{A}}$ weighted $2 F_{\mathrm{o}}-F_{\mathrm{c}}$ electron density map around the ligand is contoured at $1.0 \sigma$. (e) Cocrystal structure of 16 with TNKS2. $\sigma_{\mathrm{A}}$ weighted $2 F_{\mathrm{o}}-F_{\mathrm{c}}$ electron density map around the ligand is contoured at $1.5 \sigma$ (PDB code $5 \mathrm{NOB}$ ). (f) Superposition of $\mathbf{6}$ and $\mathbf{1 6}$ cocrystal structures showing the compounds and TNKS2 protein corresponding to TNKS2-6 cocrystal. The black dash lines represent hydrogen bonds, and the red spheres represent water molecules.

Scheme 1. Synthesis of Compound $14^{a}$<smiles>Cc1ccc(Cl)c(C(=Nc2ccccc2Cl)NN)c1</smiles><smiles>CCOC(=O)c1ccc(Nc2ccc(C#N)cc2[N+](=O)[O-])cc1</smiles>

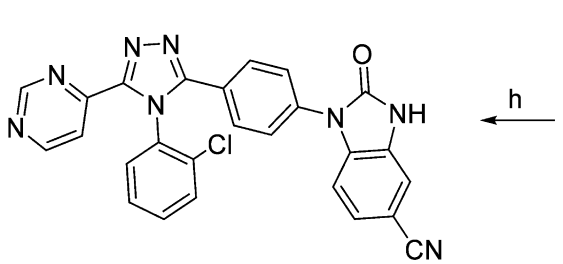

14<smiles>N#Cc1ccc2c(c1)[nH]c(=O)n2-c1ccc(C(=O)NN/C(=N/c2ccccc2Cl)c2ccncn2)cc1</smiles>

${ }^{a}$ Reagents and conditions: (a) HATU, DIPEA, dichloromethane, rt, $14 \mathrm{~h}, 68 \%$; (b) $\mathrm{PCl}_{5}, \mathrm{POCl}_{3}$, toluene, reflux, $7 \mathrm{~h}$, not isolated; (c) $\mathrm{N}_{2} \mathrm{H}_{4} \cdot \mathrm{H}_{2} \mathrm{O}$, $\mathrm{THF}, 3 \mathrm{~h}, 48 \%$; (d) $\mathrm{SnCl}_{2}$, methanol, reflux, $45 \mathrm{~min}, 92 \%$; (e) triphosgene, dichloromethane, rt, $24 \mathrm{~h}$, then reflux, $24 \mathrm{~h}, 72 \%$; (f) $\mathrm{LiOH}, \mathrm{THF} / \mathrm{H}_{2} \mathrm{O}$ (4:1), rt, overnight, 94\%; (g) 20, EDCI·HCl, HOBt, triethylamine, THF, rt, $72 \mathrm{~h}, 8 \%$; (h) toluene, reflux, $72 \mathrm{~h}, 31 \%$.

Biochemical and Cellular Activity of the Inhibitors. The five hybrid compounds were tested for their ability to inhibit TNKS2 in a biochemical assay and in the human embryonic kidney HEK293 as well as the in human colon SW480 cell line as functional assays of the $\mathrm{WNT} / \beta$-catenin signaling pathway. While compound $\mathbf{1 4}$ with a phenyl linker 
Scheme 2. Synthesis of Compounds 15, 15a and 16, 16a ${ }^{a}$<smiles>CSC(=Nc1ccccc1Cl)c1ccncn1</smiles>

24

25

26

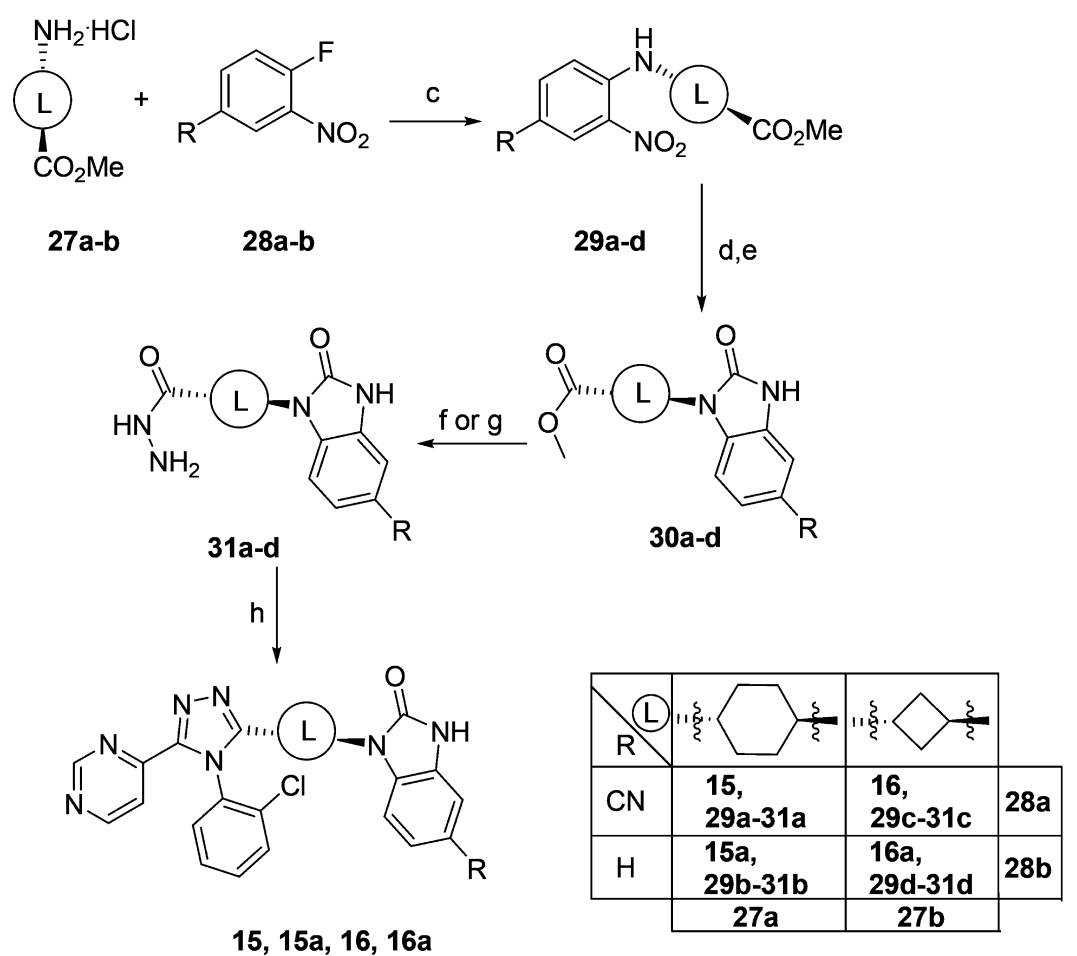

${ }^{a}$ Reagents and conditions: (a) Lawesson's reagent, toluene, $7 \mathrm{~h}$, reflux, 63\%; (b) t-BuOK, methyl tosylate, THF, rt, $18 \mathrm{~h}, 94 \%$; (c) DIPEA, acetonitrile, reflux, 24 h. 29a: 77\%. 29b: 91\%. 29c: 96\%. 29d: 95\%. (d) Pd/C, $\mathrm{H}_{2}, \mathrm{EtOH}, 2$ h, a 86\%, b 76\%, c 72\%, d 76\%; (e) triphosgene, dichloromethane, rt 24 h, reflux 24 h. 30a: 93\%. 30b: 92\%. 30c: 95\%. 30d: 92\%. (f) $\mathrm{N}_{2} \mathrm{H}_{4} \cdot \mathrm{H}_{2} \mathrm{O}$, methanol, $20{ }^{\circ} \mathrm{C}, 20$ h. 31c: 64\%. $(\mathrm{g}) \mathrm{N}_{2} \mathrm{H}_{4} \cdot \mathrm{H}_{2} \mathrm{O}$, ethanol, $80{ }^{\circ} \mathrm{C}$, 3 h. 31a: 90\%. 31b: 92\%. 31d: 90\%. (h) 26, TFA, DMA, $120{ }^{\circ} \mathrm{C}$, 14 h. 15: 10\%. 15a: 21\%. 16: 15\%. 16a: $16 \%$.

displayed moderate activity in the biochemical assays (TNKS2, $\mathrm{IC}_{50}=340 \mathrm{nM}$ ), only a weak activity was measured in the cellular assays. The trans-cyclohexane linker in 15a displayed moderate affinity versus tankyrase in the biochemical assay $\left(\mathrm{TNKS} 2, \mathrm{IC}_{50}=430 \mathrm{nM}\right)$; however, it showed moderate activity in the cellular assay (HEK293, $\mathrm{IC}_{50}=1.06 \mu \mathrm{M}$; SW480, $\left.\mathrm{IC}_{50}=1.8 \mu \mathrm{M}\right)$. By incorporation of a nitrile moiety at the benzimidazolone in $\mathbf{1 5}$, a 10 -fold increase in cellular potency $\left(\mathrm{HEK} 293, \mathrm{IC}_{50}=0.12 \mu \mathrm{M}\right.$; SW480, $\left.\mathrm{IC}_{50}=1.49 \mu \mathrm{M}\right)$ was observed, while the biochemical potency was only slightly improved. A trans-configured cyclobutane linker in 16a improved the cellular $\mathrm{IC}_{50}$ by an order of magnitude compared to 15a $\left(\mathrm{HEK} 293, \mathrm{IC}_{50}=0.2 \mu \mathrm{M}\right.$; SW480, $\left.\mathrm{IC}_{50}=0.41 \mu \mathrm{M}\right)$. When incorporating a nitrile group in 16, a further 10 -fold increase of activity was observed (HEK293, IC IC $_{50} 19 \mathrm{nM}$; SW480, $\mathrm{IC}_{50}=70 \mathrm{nM}$ ) accompanied by a favorable biochemical $\mathrm{IC}_{50}\left(\mathrm{TNKS2}, \mathrm{IC}_{50}=6.3 \mathrm{nM}\right)$, suggesting a preserved overall binding mode with similar underlying contacts for $\mathbf{1 5}$ and $\mathbf{1 6}$ which was subsequently confirmed by $\mathrm{X}$-ray crystallography (Figure 3).

Binding Mode of the Inhibitors 14 and 16. We obtained the cocrystal structures of $\mathbf{1 4}$ and $\mathbf{1 6}$ with the TNKS2 catalytic domain, and these confirmed our hypothesis of the binding mode of these hybrid compounds. Both compounds were clearly visible in the electron density, although the soaking approach used for obtaining 14 cocrystals was detrimental to the apo crystals and resolution of this data set was lower (Supporting Information Table S1). Electron density for the compound is clear, but the density for the $\mathrm{CN}$ group is essentially missing (Figure 3d). 14 was also only found in one out of two TNKS2 proteins present in the crystallographic asymmetric unit. In comparison to cocrystal structure of 6 (Figure 3a), the pyrimidine of $\mathbf{1 4}$ has rotated and forms a hydrogen bond to a water molecule. This feature is also conserved in the binding mode of 16 (Figure $3 \mathrm{e}$ ). The rigid phenyl linker in $\mathbf{1 4}$ positions the triazole deeper in the pocket and closer to the nicotinamide subpocket. Despite the conserved hydrogen bond to Tyr1060 (TNKS2) backbone amide, the distorted placement on this side of the compound is likely causing the observed lower potency (Table 1). The shorter linker found in $\mathbf{1 6}$ directs the triazole moiety in a slightly different orientation than in $\mathbf{1 4}$, and the binding mode is more similar to the template compound $\mathbf{6}$ (Figure $3 \mathrm{f}$ ). The pyrimidine is in a better position to efficiently form a displaced $\pi-\pi$ stacking interaction with the side chain of Tyr1060 yielding a better potency over the other tested linker moieties.

Profile of Tankyrase Inhibitor 16. To assess the biotarget specificity of 16, biochemical inhibition of a panel of human PARP family members was tested. Potency for TNKS1 (29 
Table 1. Activity Data in Biochemical and Cellular Assays of 14-16<smiles>[R]c1ccc2c(c1)[nH]c(=O)n2-c1ccc(-c2nnc(-c3ccncn3)n2-c2ccccc2Cl)cc1</smiles>

\begin{tabular}{|c|c|c|c|c|c|}
\hline Cmpd & $\mathrm{R}$ & $\mathrm{L}$ & $\begin{array}{c}\text { TNKS2 } \\
\mathrm{IC}_{50}(\mu \mathrm{M})\end{array}$ & $\begin{array}{c}\text { ST-Luc/Ren } \\
(\text { HEK293) } \\
\text { IC }_{50}(\mu \mathrm{M})\end{array}$ & $\begin{array}{c}\text { ST-Luc/Ren } \\
(\mathrm{SW} 480) \\
\mathrm{IC}_{50}(\mu \mathrm{M})\end{array}$ \\
\hline $\mathbf{8}^{18}$ (Reference) & - & - & 0.025 & 0.05 & 4.2 \\
\hline 14 & $-\mathrm{CN}$ & & 0.34 & $>10$ & N.D. \\
\hline $15 a$ & $-\mathrm{H}$ & & 0.43 & 1.06 & 1.80 \\
\hline 15 & $-\mathrm{CN}$ & & 0.33 & 0.12 & $1.49^{\mathrm{a}}$ \\
\hline $16 a$ & $-\mathrm{H}$ & & 0.0098 & 0.2 & 0.41 \\
\hline 16 & $-\mathrm{CN}$ & 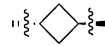 & 0.0063 & 0.019 & 0.070 \\
\hline
\end{tabular}

${ }^{a}$ Partial precipitation under assay conditions.

$\mathrm{nM}$ ) was slightly lower than for TNKS2 $(6.3 \mathrm{nM})$, and none of the other tested PARP enzymes were inhibited by 16 (Table 2).

Furthermore, a kinase selectivity profiling on 320 wild-type protein kinases of $\mathbf{1 6}$ at $10 \mu \mathrm{M}$ concentration was carried out revealing only four kinase hits with $>50 \%$ inhibition at $10 \mu \mathrm{M}$ concentration (CLK2, 73\%; MELK, 70\%; PRKG1, 66\%; TSF1, $52 \%$ ), but no kinase with $a>90 \%$ inhibition (Supporting Information Table S2). Cytochrome P450 inhibition was tested with a panel of CYP isoforms, and in vitro metabolic stability was evaluated in human hepatocytes and human liver microsomes. Of the tested CYP isoforms, 3A4 and 2C9 were significantly inhibited possibly due to the pyrimidine ring in $\mathbf{1 6}$, while CYP2C19, CYP1A, and CYP2D6 were not affected. Human hepatocyte clearance $\left(\mathrm{Cl}_{\text {int }}\right)$ was modest at $6.44((\mu \mathrm{L} /$ $\mathrm{min}) / 10^{6}$ cells $)$ and $14.8((\mu \mathrm{L} / \mathrm{min}) / \mathrm{mg}$ protein $)$, respectively (Table 2). MDCK-MDR1 permeability of $\mathbf{1 6}$ showed a moderate influx ratio and a high mean efflux ratio leading to a significant efflux ratio of 53.2 indicating an active efflux and thus a low predicted blood-brain barrier penetration (Table 2). However, an overall good oral bioavailability in mouse $(F=$ $47 \%)$, rat $(F=35 \%)$, and $\operatorname{dog}(F=91 \%)$, including a surprisingly low compound excretion in urine and feces in rat, underscored the suitability of $\mathbf{1 6}$ as a chemical tool for pharmacological in vivo evaluation.

To evaluate the antitumor effects of $\mathbf{1 6}$ in vivo, we established xenografts using the human colorectal cancer cell line COLO 320DM cells in male $\mathrm{Balb} / \mathrm{c}$ nude mice. The tumor-bearing mice were randomized into four treatment groups 2 days after inoculation: (i) vehicle control ( $1 \%$ starch, $n$ =4), (ii) $15 \mathrm{mg} / \mathrm{kg} 16(n=5)$, (iii) $30 \mathrm{mg} / \mathrm{kg} 16(n=5)$, and (iv) $60 \mathrm{mg} / \mathrm{kg} 16(n=5)$. After 10 days of once daily oral drug administration and caliper-based tumor size measurements on days 12,17 , and 21 , the experiment was terminated. Compared to vehicle control, treatment with 16 resulted in 53\%, 63\%, and $63 \%$ statistically significant tumor size reductions at $15 \mathrm{mg} / \mathrm{kg}$, $30 \mathrm{mg} / \mathrm{kg}$, and $60 \mathrm{mg} / \mathrm{kg}$ once daily oral administration, respectively (Figure 4A). In a second tumor model, we used the syngeneic leukemic p388 mouse model. Immunocompetent BDF1 (DBA2 $\times$ C57B16j) mice were implanted with p388 cells and randomized into three treatment groups consisting of six mice each after 2 days: vehicle ( $1 \%$ starch, $n=6)$ and two treatment groups for 16: $10 \mathrm{mg} / \mathrm{kg}(n=5)$ and $30 \mathrm{mg} / \mathrm{kg}(n=$ $5)$. After 10 days of once daily oral administration, the tumors sizes were measured using caliper and the experiment was ended. Compared to vehicle control, treatment with 16 resulted in $32 \%$ and $57 \%$ statistically significant tumor size reductions for $15 \mathrm{mg} / \mathrm{kg}$ and $30 \mathrm{mg} / \mathrm{kg}$ dosing, respectively (Figure 4B). No animal discomforts or body weight differences were registered throughout the experiment period. Collectively, the results show that $\mathbf{1 6}$ can significantly decrease the growth of colorectal cancer and leukemia in immunodeficient and immunocompetent models, respectively.

\section{CONCLUSIONS}

A structure guided hybridization approach based on two known inhibitors allowed us to design successfully a novel series of tankyrase inhibitors. The lead compound 16 shows high selectivity toward $\mathrm{TNKS} 1 / 2$, enhanced $\mathrm{IC}_{50}$ in biochemical assays $\left(\mathrm{TNKS} 1, \mathrm{IC}_{50}=29 \mathrm{nM}\right.$; TNKS2, $\mathrm{IC}_{50}=6.3 \mathrm{nM}$ ), and in vitro cellular assays (HEK293, $\mathrm{IC}_{50}=19 \mathrm{nM}$; SW480, $\mathrm{IC}_{50}=70$ $\mathrm{nM})$. In addition, good pharmacokinetic properties in mice and dogs and efficacy in a tumor xenograft model were achieved. The novel tankyrase inhibitor 16 expands the available small molecules space to selectively inhibit TNKS1/2 in vitro and in vivo.

\section{EXPERIMENTAL SECTION}

Chemistry. All chemicals were purchased from commercial suppliers Activate Scientific, Sigma-Aldrich, and Alfa Aesar and used as received unless otherwise specified. NMR spectra were recorded at either $295 \mathrm{~K}(300 \mathrm{MHz})$ or $300 \mathrm{~K}(600 \mathrm{MHz})$ at either Bruker AV $300(300 \mathrm{MHz}, 75 \mathrm{MHz})$ or Bruker AV $600(600 \mathrm{MHz}, 151 \mathrm{MHz})$ 
Table 2. Summary of Activity and Selectivity Data as Well as Physicochemical and ADME Properties of the Tankyrase Inhibitor $16^{a}$

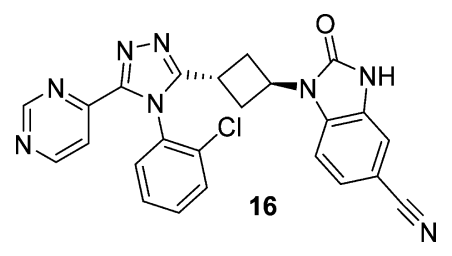

\begin{tabular}{|c|c|}
\hline property & value \\
\hline molecular weight & 468.9 \\
\hline $\operatorname{cLog} \mathrm{P}^{b}$ & 3.39 \\
\hline hydrogen bond donors & 1 \\
\hline hydrogen bond acceptors & 6 \\
\hline number of rotatable bonds & 4 \\
\hline $\mathrm{PSA}^{b}$ & $112.6 \AA^{2}$ \\
\hline aqueous solubility $\left(\mathrm{pH}=7.4,25^{\circ} \mathrm{C}\right)$ & $31.2 \mu \mathrm{M}$ \\
\hline ligand efficiency $(\mathrm{LE})^{b}$ & 0.34 \\
\hline $\mathrm{IC}_{50}$ TNKS1 $\left(\mathrm{pIC}_{50} \pm \mathrm{SD}\right)^{c}$ & $0.029 \mu \mathrm{M}(7.54 \pm 0.07)$ \\
\hline $\mathrm{IC}_{50} \mathrm{TNKS}_{2}\left(\mathrm{pIC}_{50} \pm \mathrm{SD}\right)^{c}$ & $0.0063 \mu \mathrm{M}(8.20 \pm 0.03)$ \\
\hline $\mathrm{IC}_{50}(\mathrm{ST}$-Luc/Ren in HEK293) & $0.019 \mu \mathrm{M}$ \\
\hline $\mathrm{IC}_{50}(\mathrm{ST}-\mathrm{Luc} / \mathrm{Ren}$ in SW480) & $0.070 \mu \mathrm{M}$ \\
\hline $\mathrm{IC}_{50}$ ARTD1/PARP1 & $>100 \mu \mathrm{M}$ \\
\hline $\mathrm{IC}_{50}$ ARTD2/PARP2 & $>100 \mu \mathrm{M}$ \\
\hline $\mathrm{IC}_{50}$ ARTD3/PARP3 & $>100 \mu \mathrm{M}$ \\
\hline $\mathrm{IC}_{50}$ ARTD4/PARP4 & $>100 \mu \mathrm{M}$ \\
\hline $\mathrm{IC}_{50}$ ARTD7/PARP15 & $>10 \mu \mathrm{M}^{d}$ \\
\hline $\mathrm{IC}_{50}$ ARTD8/PARP14 & $>10 \mu \mathrm{M}^{d}$ \\
\hline $\mathrm{IC}_{50}$ ARTD10/PARP10 & $>10 \mu \mathrm{M}^{d}$ \\
\hline $\mathrm{IC}_{50}$ ARTD12/PARP12 & $>10 \mu \mathrm{M}^{d}$ \\
\hline $\mathrm{IC}_{50}$ ARTD15/PARP16 & $>10 \mu \mathrm{M}^{d}$ \\
\hline kinase selectivity: kinases with $>50 \%$ inhibition at $10 \mu \mathrm{M}$ & $4 / 320$ \\
\hline clearance human liver microsomes $\left(\mathrm{Cl}_{\mathrm{int}}\right)$ & $14.8((\mu \mathrm{L} / \mathrm{min}) / \mathrm{mg}$ protein $)$ \\
\hline clearance human hepatocyte $\left(\mathrm{Cl}_{\mathrm{int}}\right)$ & $6.44\left((\mu \mathrm{L} / \mathrm{min}) / 10^{6}\right.$ cells $)$ \\
\hline MDCK-MDR1 permeability & $5.3 \times 10^{-7} \mathrm{~cm} / \mathrm{s}(\mathrm{A}-\mathrm{B})$ \\
\hline$P_{\text {app }}$ at $10 \mu \mathrm{M}$ & $28.2 \times 10^{-7} \mathrm{~cm} / \mathrm{s}(\mathrm{B}-\mathrm{A})$ \\
\hline CYP $(3 \mathrm{~A} 4,2 \mathrm{C} 9,2 \mathrm{C} 19,2 \mathrm{D} 6 / 1 \mathrm{~A})$ & $1.3 \mu \mathrm{M}, 11.9 \mu \mathrm{M},>25 \mu \mathrm{M},>25 \mu \mathrm{M},>25 \mu \mathrm{M}$ \\
\hline mouse PK (po, $5 \mathrm{mg} / \mathrm{kg}$ ) & $F=47 \% ; t_{1 / 2}=1.5 \mathrm{~h} ; C_{\max }=123.5 \mathrm{ng} / \mathrm{mL} ; \mathrm{AUC}_{(0-t)}=144.7 \mathrm{~h} \cdot \mathrm{ng} / \mathrm{mL} ; \mathrm{CL}=34.02 \mathrm{~L} / \mathrm{kg}$ \\
\hline rat $\mathrm{PK}(\mathrm{po}, 14 \mathrm{mg} / \mathrm{kg})$ & $F=35 \% ; t_{1 / 2} \mathrm{NA} ; C_{\max }=843 \mathrm{ng} / \mathrm{mL} ; \mathrm{AUC}_{(0-t)}=2765 \mathrm{~h} \cdot \mathrm{ng} / \mathrm{mL} ; \mathrm{CL} \mathrm{NA}$ \\
\hline $\operatorname{dog}$ PK (po, 7 mg/kg) & $F=91 \% ; t_{1 / 2}=4.7 \mathrm{~h} ; C_{\max }=5851 \mathrm{ng} / \mathrm{mL} ; \mathrm{AUC}_{(0-t)}=27134 \mathrm{~h} \cdot \mathrm{ng} / \mathrm{mL} ; \mathrm{CL}=0.14 \mathrm{~L} / \mathrm{kg}$ \\
\hline
\end{tabular}

${ }^{a}$ For further details see Supporting Information. ${ }^{b}$ Calculated properties using ChemAxon package, version 16.1, 2010-2016. ${ }^{c}$ SD $=$ standard deviation. ${ }^{d}$ No inhibition; concentration limited by low DMSO tolerance of the enzymes.

spectrometers. Chemical shifts are reported in $\mathrm{ppm}(\delta)$ referenced to TMS $(\delta=0.00 \mathrm{ppm})$, DMSO $(2.50 \mathrm{ppm})$, and $\mathrm{CHCl}_{3}(7.26 \mathrm{ppm})$. Melting points were recorded in open capillaries on a Büchi B-545 melting point apparatus. Temperatures are expressed in degrees Celsius $\left({ }^{\circ} \mathrm{C}\right)$ and are uncorrected.

LC/MS analysis was performed on an Agilent LC/MS 1260 analytical HPLC with DAD coupled to an Agilent 6120 single quadrupole mass spectrometer (ESI-SQ) equipped with a Thermo Fisher Scientific Accucore C18 column, $2.1 \mathrm{~mm} \times 30 \mathrm{~mm}, 2.6 \mu \mathrm{m}$. Method: ESI+, flux of $0.8 \mathrm{~mL} / \mathrm{min}, 5-95 \% \mathrm{CH}_{3} \mathrm{CN}$ in $\mathrm{H}_{2} \mathrm{O}+0.1 \%$ $\mathrm{FA}$, total run time of $2.5 \mathrm{~min}$. High resolution mass spectra were recorded on an Agilent 6220A accurate-mass time-of-flight mass spectrometer (ESI-TOF) with Agilent 1200 HPLC/DAD front-end. The HPLC was equipped with an Agilent Poroshell 120, C18 column, $2.1 \mathrm{~mm} \times 100 \mathrm{~mm}, 1.8 \mu \mathrm{m}$. Method: ESI+, flux of $0.6 \mathrm{~mL} / \mathrm{min}, 5-$ $99 \% \mathrm{CH}_{3} \mathrm{CN}$ in $\mathrm{H}_{2} \mathrm{O}+0.1 \% \mathrm{FA}$, total runtime of $4.5 \mathrm{~min}$.

Purity and characterization of all final compounds were established by a combination of LC-MS, LC-HRMS, and NMR analytical techniques. All compounds were found to be $>95 \%$ pure by LC-MS and LC-HRMS analysis.

Preparation of 1-(4-(4-(2-Chlorophenyl)-5-(pyrimidin-4-yl)4H-1,2,4-triazol-3-yl)phenyl)-2,3-dihydro-2-oxo-1H-benzo[d]- imidazole-5-carbonitrile (14). (i) N-(2-Chlorophenyl)pyrimidine-4carboxamide (24). To a flask charged with pyrimidine-4-carboxylic acid (17) $(1.4 \mathrm{~g}, 11.28 \mathrm{mmol})$ were added dichloromethane $(50 \mathrm{~mL})$, $\mathrm{N}, \mathrm{N}$-diisopropylethylamine $(5.89 \mathrm{~mL}, 33.84 \mathrm{mmol})$, HATU $(4.75 \mathrm{~g}$, $12.4 \mathrm{mmol})$, and 2-chlorobenzenamine $(18)(1.18 \mathrm{~mL}, 11.28 \mathrm{mmol})$, respectively. The resulting mixture was stirred overnight at room temperature. Water was added to reaction mixture, and the organic layer was separated using a separating funnel. The organic layer was dried over magnesium sulfate, filtered and concentrated in vacuo, and subjected to column chromatography on silica gel using a cyclohexane and ethyl acetate gradient as eluent to afford $\mathrm{N}$-(2-chlorophenyl)pyrimidine-4-carboxamide (24) as an amorphous solid. Yield $1.79 \mathrm{~g}$ (68\%). MS (ESI) for $\mathrm{C}_{11} \mathrm{H}_{8} \mathrm{ClN}_{3} \mathrm{O}+\mathrm{H}^{+},[\mathrm{M}+\mathrm{H}]^{+} \mathrm{m} / z$, calcd 234.0, found 234.1. ${ }^{1} \mathrm{H}$ NMR (300 MHz, $\left.\mathrm{CDCl}_{3}\right) \delta 10.57(\mathrm{~s}, 1 \mathrm{H}), 9.37(\mathrm{~s}$, $1 \mathrm{H}), 9.05(\mathrm{~d}, J=5.0 \mathrm{~Hz}, 1 \mathrm{H}), 8.61(\mathrm{dd}, J=8.2,1.6 \mathrm{~Hz}, 1 \mathrm{H}), 8.22(\mathrm{~d}, J$ $=5.0 \mathrm{~Hz}, 1 \mathrm{H}), 7.44(\mathrm{dd}, J=8.1,1.5 \mathrm{~Hz}, 1 \mathrm{H}), 7.35(\mathrm{td}, J=7.9,1.6 \mathrm{~Hz}$, $1 \mathrm{H}), 7.19-7.06(\mathrm{~m}, 1 \mathrm{H}) .{ }^{13} \mathrm{C} \mathrm{NMR}\left(75 \mathrm{MHz}, \mathrm{CDCl}_{3}\right) \delta 160.3,159.4$, $157.8,156.1,133.9,129.2,127.7,125.3,123.6,121.1,118.5$.

(ii) (Z)- $N^{\prime \prime}$-(2-Chlorophenyl)pyrimidine-4-carboximidhydrazide (20). To a solution of $\mathrm{N}$-(2-chlorophenyl)pyrimidine-4-carboxamide (24) $(450 \mathrm{mg}, 1.92 \mathrm{mmol})$ in toluene $(20 \mathrm{~mL})$ were added phosphorus pentachloride $(1.2 \mathrm{~g}, 5.77 \mathrm{mmol})$ and phosphoryl chloride 

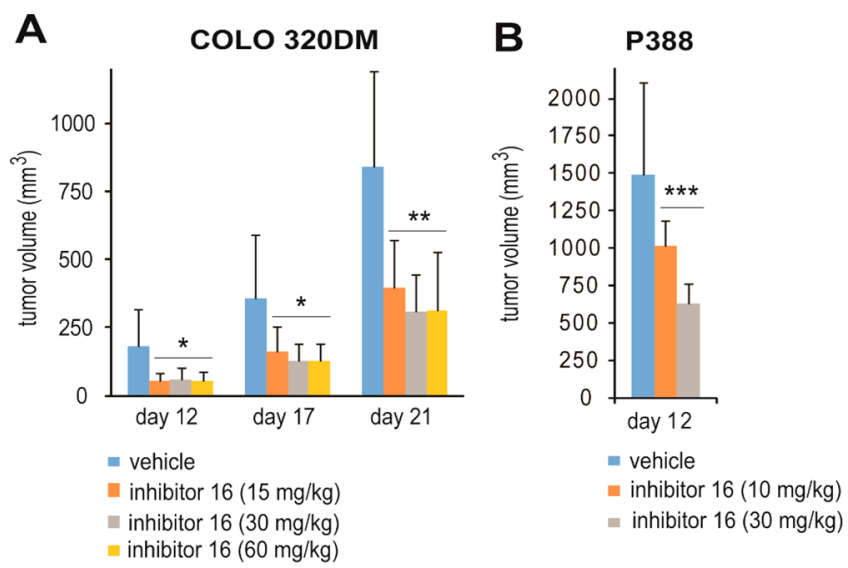

Figure 4. Antitumor activity of $\mathbf{1 6}$ in xenograft models: (A) COLO $320 \mathrm{DM}$ colon cancer xenograft; (B) isogenic p388 leukemia mice model. Shown is reduction of tumor volume $\left(\mathrm{mm}^{3}\right)$ versus vehicle treated controls (blue) after once daily oral dosing of 16 at various depicted doses. Statistical significance is indicated: ANOVA on Ranks/ Dunn's method, $P<0.05(*)$, one-way ANOVA/Holm-Sidak method, $P<0.001(* *)$, and one-tailed $P<0.05$ (***).

( $540 \mu \mathrm{L}, 5.77 \mathrm{mmol}$ ), and the mixture was stirred at reflux for $7 \mathrm{~h}$. The solvents were then evaporated to achieve (Z)-N-(2-chlorophenyl)pyrimidine-4-carbimidoyl chloride (19) as intermediate and $3 \mathrm{~mL}$ of hydrazine hydrate was added and stirred for $4 \mathrm{~h}$ at room temperature. Solvents were evaporated and subjected to column chromatography on silica gel using a cyclohexane and ethyl acetate gradient as eluent to afford (Z)- $N^{\prime \prime}$-(2-chlorophenyl)pyrimidine-4-carboximidhydrazide (20) as a yellow foam. Yield: $230 \mathrm{mg}(48 \%) .{ }^{1} \mathrm{H}$ NMR $(300 \mathrm{MHz}$, DMSO- $\left.d_{6}\right) \delta 9.05-8.98(\mathrm{~m}, 1 \mathrm{H}), 8.66(\mathrm{~d}, J=5.5 \mathrm{~Hz}, 1 \mathrm{H}), 7.86(\mathrm{dd}, J$ $=5.5,1.0 \mathrm{~Hz}, 1 \mathrm{H}), 7.44-7.35(\mathrm{~m}, 1 \mathrm{H}), 7.30(\mathrm{~s}, 2 \mathrm{H}), 7.18-7.04(\mathrm{~m}$, $2 \mathrm{H}), 6.87-6.72(\mathrm{~m}, 1 \mathrm{H}), 6.22(\mathrm{~d}, J=7.9 \mathrm{~Hz}, 1 \mathrm{H}) .{ }^{13} \mathrm{C}$ NMR $(75$ MHz, DMSO- $\left.d_{6}\right) \delta 160.2,158.5,156.6,138.8,133.2,129.5,127.9$, 120.6, 120.5, 116.6, 116.1 .

(iii) 4-(6-Cyano-1,2-dihydro-2-oxobenzo[d]imidazol-3-yl)benzoic Acid (22). To a solution of ethyl 4-(4-cyano-2-nitrophenylamino)benzoate $(21)(891 \mathrm{mg}, 2.86 \mathrm{mmol})$ in $\mathrm{EtOH}(20 \mathrm{~mL})$ was added $\mathrm{SnCl}_{2}(5.55 \mathrm{~g}, 29.2 \mathrm{mmol})$. The orange mixture was refluxed for 45 min. It was then poured into EtOAc. The organic layer was washed with $1 \mathrm{~N} \mathrm{HCl}(50 \mathrm{~mL})$, brine, and saturated $\mathrm{NaHCO}_{3}$ and dried over $\mathrm{Na}_{2} \mathrm{SO}_{4}$. After evaporation of the solvents under reduced pressure the residue was purified by column chromatography on silica gel with $25 \%$ EtOAc in hexanes to afford ethyl 4-(2-amino-4-cyanophenylamino)benzoate as a pale yellow foam. Yield: $743 \mathrm{mg}(92 \%) .{ }^{1} \mathrm{H}$ NMR (300 $\left.\mathrm{MHz}, \mathrm{CDCl}_{3}\right) \delta \mathrm{ppm} 7.98-7.95(\mathrm{~m}, 2 \mathrm{H}), 8.25(\mathrm{~d}, J=6.0 \mathrm{~Hz}, 1 \mathrm{H})$, 7.11-7.06 (m, 2H), 6.89-6.85 (m, 2H), $5.71(\mathrm{~s}, 1 \mathrm{H}), 4.38-4.32(\mathrm{~m}$, $2 \mathrm{H}), 4.00-3.70(\mathrm{~m}, 2 \mathrm{H}), 1.40-1.36(\mathrm{~m}, 3 \mathrm{H})$. To a mixture of ethyl 4(2-amino-4-cyanophenylamino)benzoate $(320 \mathrm{mg}, 1.21 \mathrm{mmol})$ in dichloromethane $(50 \mathrm{~mL})$ under ice-water bath cooling triphosgene $(573 \mathrm{mg}, 1.93 \mathrm{mmol})$ was added. The mixture was stirred at $0{ }^{\circ} \mathrm{C}$ for 1 h. Then it was allowed to warm to room temperature and stirred overnight. The resulting mixture was then refluxed overnight. It was diluted with dichloromethane, washed with saturated $\mathrm{NaHCO}_{3}$ and brine, and evaporated to give a white solid ethyl 4-(6-cyano-1,2dihydro-2-oxobenzo[d]imidazol-3-yl)benzoate. Yield: $254 \mathrm{mg}$ (72\%). ${ }^{1} \mathrm{H}$ NMR $\left(300 \mathrm{MHz}, \mathrm{CDCl}_{3}\right) \delta \mathrm{ppm} 9.55(\mathrm{~s}, 1 \mathrm{H}), 8.29-8.26(\mathrm{~m}, 2 \mathrm{H})$, $7.66-7.30(\mathrm{~m}, 2 \mathrm{H}), 7.45-7.42(\mathrm{~m}, 2 \mathrm{H}), 7.18-7.15(\mathrm{~m}, 1 \mathrm{H}), 4.45(\mathrm{q}, J$ $=5.4 \mathrm{~Hz}, 2 \mathrm{H}), 1.44(\mathrm{t}, J=5.4 \mathrm{~Hz}, 3 \mathrm{H})$. To a mixture of ethyl 4-(6cyano-1,2-dihydro-2-oxobenzo[d]imidazol-3-yl)benzoate $(400 \mathrm{mg}$, $1.30 \mathrm{mmol})$ in $\mathrm{THF} / \mathrm{H}_{2} \mathrm{O}(4: 1 \mathrm{v} / \mathrm{v}, 15 \mathrm{~mL})$ was added $\mathrm{LiOH}$ monohydrate $(133 \mathrm{mg}, 3.16 \mathrm{mmol})$. The mixture was stirred overnight at room temperature and was then acidified with $1 \mathrm{~N} \mathrm{HCl}$. The resulting precipitate was collected by filtration to give 4-(6-cyano-1,2dihydro-2-oxobenzo[ $d$ ]imidazol-3-yl)benzoic acid (22) as a greasy solid. Yield: $340 \mathrm{mg}$ (94\%). ${ }^{1} \mathrm{H}$ NMR $\left(300 \mathrm{MHz}, \mathrm{CDCl}_{3}\right) \delta \mathrm{ppm} 8.09$ $(\mathrm{d}, J=6.6 \mathrm{~Hz}, 2 \mathrm{H}), 7.67(\mathrm{~d}, J=6.6 \mathrm{~Hz}, 2 \mathrm{H}), 7.50-7.44(\mathrm{~m}, 2 \mathrm{H}), 7.19$ $(\mathrm{d}, J=6.0 \mathrm{~Hz}, 1 \mathrm{H}), 7.08-7.02$ and $6.82-6.76(\mathrm{~m}, 1 \mathrm{H})$.

(iv) $N^{\prime}-((Z)-(2-C h l o r o p h e n y l i m i n o)(p y r i m i d i n-4-y l) m e t h y l)-4-(6-$ cyano-1,2-dihydro-2-oxobenzo[d]imidazol-3-yl)benzohydrazide (23). To a mixture of 4-(6-cyano-1,2-dihydro-2-oxobenzo[d]imidazol3-yl)benzoic acid (22) $(271 \mathrm{mg}, 0.97 \mathrm{mmol})$ in THF $(35 \mathrm{~mL})$ were sequentially added $(Z)-N^{\prime \prime}$-(2-chlorophenyl)pyrimidine-4-carboximidhydrazide (20) (331 mg, $1.34 \mathrm{mmol})$, EDCI. $\mathrm{HCl}$ (323 mg, 1.68 $\mathrm{mmol})$, HOBt (175 mg, $1.30 \mathrm{mmol})$, and $\mathrm{Et}_{3} \mathrm{~N}(1.5 \mathrm{~mL}, 10.8 \mathrm{mmol})$. The mixture was stirred for $3 \mathrm{~d}$. It was diluted with dichloromethane, washed with water, saturated $\mathrm{NaHCO}_{3}$, dried over $\mathrm{Na}_{2} \mathrm{SO}_{4}$. After filtration and evaporation of the solvents under reduced pressure the residue was purified by column chromatography on silica gel with $5 \%$ $\mathrm{MeOH}$ in dichloromethane as an eluent to afford $N^{\prime}-((Z)-(2-$ chlorophenylimino)(pyrimidin-4-yl)methyl)-4-(6-cyano-1,2-dihydro2-oxobenzo[d]imidazol-3-yl)benzohydrazide (23) as a pale yellow foam. Yield: $40 \mathrm{mg}(8 \%) .{ }^{1} \mathrm{H}$ NMR (300 MHz, DMSO- $\left.d_{6}\right) \delta \mathrm{ppm}$ $11.65(\mathrm{~s}, 1 \mathrm{H}), 9.04(\mathrm{~s}, 1 \mathrm{H}), 8.89-8.87(\mathrm{~m}, 1 \mathrm{H}), 8.01-7.92(\mathrm{~m}, 1 \mathrm{H})$, 7.91-7.82 (m, $2 \mathrm{H}), 7.64-7.58(\mathrm{~m}, 3 \mathrm{H}), 7.50-7.35(\mathrm{~m}, 4 \mathrm{H}), 7.18-$ $7.02(\mathrm{~m}, 2 \mathrm{H}), 7.00-6.92(\mathrm{~m}, 1 \mathrm{H}) .6 .75-6.68(\mathrm{~m}, 1 \mathrm{H})$.

(v) 1-(4-(4-(2-Chlorophenyl)-5-(pyrimidin-4-yl)-4H-1,2,4-triazol-3yl) phenyl)-2,3-dihydro-2-oxo-1H-benzo[d]imidazole-5-carbonitrile (14). A mixture of $N^{\prime}-((Z)$-(2-chlorophenylimino)(pyrimidin-4-yl)methyl)-4-(6-cyano-1,2-dihydro-2-oxobenzo[d]imidazol-3-yl)benzohydrazide $(23)(20 \mathrm{mg}, 0.039 \mathrm{mmol})$ in toluene $(10 \mathrm{~mL})$ was refluxed for $3 \mathrm{~d}$. The mixture was evaporated and subjected to column chromatography on silica gel with $2 \% \mathrm{MeOH}$ in dichloromethane to give the crude product, which was washed with $\mathrm{Et}_{2} \mathrm{O}$ to afford the title compound 1-(4-(4-(2-chlorophenyl)-5-(pyrimidin-4-yl)-4H-1,2,4-triazol-3-yl)phenyl)-2,3-dihydro-2-oxo-1H-benzo[d]imidazole-5-carbonitrile (14) as a pale yellow solid. Yield: $6 \mathrm{mg}(31 \%)$. Mp $182{ }^{\circ} \mathrm{C}$. MS for $\mathrm{C}_{26} \mathrm{H}_{15} \mathrm{ClN}_{8} \mathrm{O}-\mathrm{H}^{+},[\mathrm{M}-\mathrm{H}]^{-} \mathrm{m} / z$, calcd 489.1 , found 489.3 . ${ }^{1} \mathrm{H}$ $\operatorname{NMR}\left(300 \mathrm{~Hz}, \mathrm{CDCl}_{3}+\mathrm{CD}_{3} \mathrm{OD}\right) \delta 8.82-8.00(\mathrm{~m}, 2 \mathrm{H}), 8.28-8.26$ $(\mathrm{m}, 1 \mathrm{H}), 7.66-7.60(\mathrm{~m}, 2 \mathrm{H}), 7.54-7.44(\mathrm{~m}, 4 \mathrm{H}), 7.40-7.32(\mathrm{~m}, 4 \mathrm{H})$, $7.08-7.06(\mathrm{~m}, 1 \mathrm{H})$.

Preparation of 1-((trans)-4-(4-(2-Chlorophenyl)-5-(pyrimidin-4-yl)-4H-1,2,4-triazol-3-yl)cyclohexyl)-1H-benzo[d]imidazol-2(3H)-one (15a). (i) N-(2-Chlorophenyl)pyrimidine-4carbothioamide (25). To a solution of $N$-(2-chlorophenyl)pyrimidine-4-carboxamide $(24)(2.0 \mathrm{~g}, 8.55 \mathrm{mmol})$ in toluene $(20$ $\mathrm{mL})$, Lawesson's reagent $(2.42 \mathrm{~g}, 5.99 \mathrm{mmol})$ was added, and the mixture was refluxed for $7 \mathrm{~h}$. After the reaction mixture was cooled to room temperature, the solvents were evaporated. The crude product was purified by chromatography on silica gel, eluting with a gradient of cyclohexane/ethyl acetate. The fractions containing the product were combined and the solvent was evaporated under reduced pressure to yield $\mathrm{N}$-(2-chlorophenyl)pyrimidine-4-carbothioamide (25) as an amorphous solid. Yield: $1.34 \mathrm{~g}(63 \%)$. HRMS for $\mathrm{C}_{11} \mathrm{H}_{8} \mathrm{ClN}_{3} \mathrm{~S}+$ $\mathrm{H}^{+},[\mathrm{M}+\mathrm{H}]^{+} \mathrm{m} / z$, calcd 250.0200 , found $250.0206 .{ }^{1} \mathrm{H}$ NMR (300 $\left.\mathrm{MHz}, \mathrm{CDCl}_{3}\right) \delta 12.39(\mathrm{~s}, 1 \mathrm{H}), 9.32(\mathrm{~s}, 1 \mathrm{H}), 9.09(\mathrm{~d}, J=8.2 \mathrm{~Hz}, 1 \mathrm{H})$, $9.02(\mathrm{~d}, J=5.2 \mathrm{~Hz}, 1 \mathrm{H}), 8.65(\mathrm{~d}, J=5.2 \mathrm{~Hz}, 1 \mathrm{H}), 7.54(\mathrm{dd}, J=8.0,1.5$ $\mathrm{Hz}, 1 \mathrm{H}), 7.41(\mathrm{t}, J=7.8 \mathrm{~Hz}, 1 \mathrm{H}), 7.27(\mathrm{td}, J=7.7,1.5 \mathrm{~Hz}, 1 \mathrm{H}) .{ }^{13} \mathrm{C}$ NMR $\left(75 \mathrm{MHz}, \mathrm{CDCl}_{3}\right) \delta 185.5,158.6,157.0,156.5,134.9,129.7$, $127.5,127.1,126.7,123.4,120.3$.

(ii) Methyl (Z)-N-(2-Chlorophenyl)pyrimidine-4-carbimidothioate (26). To a flask charged with $N$-(2-chlorophenyl)pyrimidine-4carbothioamide (25) $(249.7 \mathrm{mg}, 1.0 \mathrm{mmol})$ in tetrahydrofuran (6 $\mathrm{mL}$ ) was added potassium tert-butoxide $(112.2 \mathrm{mg}, 1.0 \mathrm{mmol})$, and the mixture was stirred for $15 \mathrm{~min}$. Methyl tosylate $(151 \mu \mathrm{L}, 1.0 \mathrm{mmol})$ was then added dropwise and the reaction mixture was stirred at room temperature for further $18 \mathrm{~h}$. The reaction mixture was then partitioned between water and ethyl acetate, the layers were separated, and the organic layer was washed twice with water and brine, dried over magnesium sulfate, filtered, and evaporated under reduced pressure to provide crude product. The crude greasy product methyl (Z)-N-(2-chlorophenyl)pyrimidine-4-carbimidothioate (26) was directly used in the next reaction step without any purification. Yield: $248 \mathrm{mg}$ (94\%). HRMS for $\mathrm{C}_{12} \mathrm{H}_{10} \mathrm{ClN}_{3} \mathrm{~S}+\mathrm{H}^{+},[\mathrm{M}+\mathrm{H}]^{+} \mathrm{m} / z$, calcd 264.0357, found 264.0369.

(iii) (trans)-Methyl 4-(2-Nitrophenylamino)cyclohexanecarboxylate (29b). To a solution of (trans)-methyl-4-aminocyclohex- 
ane carboxylate hydrochloride $(27 \mathrm{a})(1 \mathrm{~g}, 5.16 \mathrm{mmol})$ and 1-fluoro-2nitrobenzene $(\mathbf{2 8 b})(544 \mu \mathrm{L}, 5.16 \mathrm{mmol})$ in acetonitrile $(50 \mathrm{~mL})$, potassium carbonate $(1.06 \mathrm{~g}, 77.4 \mathrm{mmol})$ was added at ambient temperature. The resulting reaction mixture was heated for $8 \mathrm{~h}$ at reflux. After cooling to room temperature, the acetonitrile was removed under reduced pressure and the crude solid was dissolved in dichloromethane. The dichloromethane layer was washed with water, dried over magnesium sulfate, filtered, and then concentrated under reduced pressure. The crude solid product was washed with cold methanol to yield (trans)-methyl 4-(2-nitrophenylamino)cyclohexanecarboxylate (29b) as a yellow solid which was used in the next reaction step without any further purification. Yield: $1.3 \mathrm{~g}$ (91\%). Mp 81-83 ${ }^{\circ} \mathrm{C}$. HRMS for $\mathrm{C}_{14} \mathrm{H}_{18} \mathrm{~N}_{2} \mathrm{O}_{4}+\mathrm{H}^{+},[\mathrm{M}+\mathrm{H}]^{+} \mathrm{m} / z$, calcd 279.1339, found 279.1350. ${ }^{1} \mathrm{H}$ NMR $\left(600 \mathrm{MHz}, \mathrm{DMSO}-d_{6}\right) \delta 8.08-8.00(\mathrm{~m}$, $1 \mathrm{H}), 7.89(\mathrm{~d}, J=8.0 \mathrm{~Hz}, 1 \mathrm{H}), 7.51(\mathrm{q}, J=9.4,8.8 \mathrm{~Hz}, 1 \mathrm{H}), 7.14(\mathrm{t}, J=$ $9.2 \mathrm{~Hz}, 1 \mathrm{H}), 6.67(\mathrm{q}, J=10.4,9.1 \mathrm{~Hz}, 1 \mathrm{H}), 3.67-3.53(\mathrm{~m}, 4 \mathrm{H}), 2.40-$ $2.31(\mathrm{~m}, 1 \mathrm{H}), 2.09-2.03(\mathrm{~m}, 2 \mathrm{H}), 1.95(\mathrm{~d}, J=14.4 \mathrm{~Hz}, 2 \mathrm{H}), 1.61-$ $1.51(\mathrm{~m}, 2 \mathrm{H}), 1.38(\mathrm{q}, J=15.4,13.0 \mathrm{~Hz}, 2 \mathrm{H}) .{ }^{13} \mathrm{C} \mathrm{NMR}(151 \mathrm{MHz}$, DMSO- $\left.d_{6}\right) \delta 175.1,144.3,136.6,130.8,126.3,115.3,114.9,51.3,49.8$, 41.3, 31.0, 27.2.

(iv) (trans)-Methyl 4-(1,2-Dihydro-2-oxobenzo[d]imidazol-3-yl)cyclohexanecarboxylate (30b). A reaction flask with a mixture of (trans)-methyl 4-(2-nitrophenylamino)cyclohexanecarboxylate (29b) $(1.85 \mathrm{~g}, 9.55 \mathrm{mmol})$ and a catalytic amount of $10 \%$ palladium on charcoal in ethanol $(400 \mathrm{~mL})$ was equipped with a hydrogen balloon, and hydrogen gas was bubbled through the reaction mixture at atmospheric pressure. After $2 \mathrm{~h}$, the balloon was removed and the reaction mixture purged with nitrogen, filtered through a pad of Celite, and washed twice with ethanol. The filtrate was concentrated under reduced pressure to afford (trans)-methyl 4-(2-aminophenylamino)cyclohexanecarboxylate as a yellow greasy solid. Yield: $1.25 \mathrm{~g}(76 \%)$. HRMS for $\mathrm{C}_{14} \mathrm{H}_{20} \mathrm{~N}_{2} \mathrm{O}_{2}+\mathrm{H}^{+},[\mathrm{M}+\mathrm{H}]^{+} \mathrm{m} / z$, calcd 249.1598, found 249.1599. ${ }^{1} \mathrm{H}$ NMR $\left(600 \mathrm{MHz}\right.$, DMSO- $\left.d_{6}\right) \delta 6.58(\mathrm{~d}, J=7.7 \mathrm{~Hz}, 1 \mathrm{H})$, $6.51(\mathrm{t}, J=4.1 \mathrm{~Hz}, 2 \mathrm{H}), 6.42(\mathrm{td}, J=7.9,3.8 \mathrm{~Hz}, 1 \mathrm{H}), 4.88(\mathrm{~s}, 3 \mathrm{H})$, $3.60(\mathrm{t}, J=4.4 \mathrm{~Hz}, 3 \mathrm{H}), 3.17(\mathrm{q}, J=7.8,4.7 \mathrm{~Hz}, 1 \mathrm{H}), 2.31(\mathrm{tt}, J=15.4$, $4.8 \mathrm{~Hz}, 1 \mathrm{H}), 2.07-2.00(\mathrm{~m}, 2 \mathrm{H}), 1.97-1.91(\mathrm{~m}, 2 \mathrm{H}), 1.47(\mathrm{qd}, J=$ $13.3,3.9 \mathrm{~Hz}, 2 \mathrm{H}), 1.21(\mathrm{dq}, J=17.8,7.2,4.6 \mathrm{~Hz}, 2 \mathrm{H}) .{ }^{13} \mathrm{C}$ NMR $(151$ $\left.\mathrm{MHz}, \mathrm{DMSO}-d_{6}\right) \delta 175.3,134.7,134.3,118.1,117.2,115.1,111.5$, $51.3,50.8,42.0,31.5,27.6$. To a mixture of (trans)-methyl 4-(2aminophenylamino)cyclohexanecarboxylate $(1.00 \mathrm{~g}, 4.02 \mathrm{mmol})$ in dichloromethane $(70 \mathrm{~mL})$ at $0{ }^{\circ} \mathrm{C}$ (ice bath) was added triphosgene $(1.79 \mathrm{~g}, 6.03 \mathrm{mmol})$. The mixture was stirred at $0{ }^{\circ} \mathrm{C}$ for $1 \mathrm{~h}$. Then it was allowed to warm to room temperature and stirred for $24 \mathrm{~h}$. Next the resulting mixture was refluxed for $24 \mathrm{~h}$. The reaction mixture was diluted with dichloromethane and washed with saturated sodium bicarbonate and brine, dried over magnesium sulfate, filtered, and evaporated to give (trans)-methyl 4-(1,2-dihydro-2-oxobenzo[d]imidazol-3-yl)cyclohexanecarboxylate (30b) as an amorphous solid. Yield: $950 \mathrm{mg}(86 \%)$. HRMS for $\mathrm{C}_{15} \mathrm{H}_{18} \mathrm{~N}_{2} \mathrm{O}_{3}+\mathrm{H}^{+},[\mathrm{M}+\mathrm{H}]^{+} \mathrm{m} / z$, calcd 275.1390, found 275.1403. ${ }^{1} \mathrm{H}$ NMR $\left(600 \mathrm{MHz}\right.$, DMSO- $\left.d_{6}\right) \delta$ $10.80(\mathrm{~d}, J=5.1 \mathrm{~Hz}, 1 \mathrm{H}), 7.30(\mathrm{t}, J=6.6 \mathrm{~Hz}, 1 \mathrm{H}), 6.95(\mathrm{~d}, J=5.6 \mathrm{~Hz}$, $3 \mathrm{H}), 4.19-4.11(\mathrm{~m}, 1 \mathrm{H}), 3.64-3.58(\mathrm{~m}, 3 \mathrm{H}), 2.21(\mathrm{q}, J=12.8 \mathrm{~Hz}$, $2 \mathrm{H}), 2.04(\mathrm{~d}, J=13.2 \mathrm{~Hz}, 2 \mathrm{H}), 1.72(\mathrm{~d}, J=12.5 \mathrm{~Hz}, 2 \mathrm{H}), 1.53(\mathrm{q}, J=$ $12.9 \mathrm{~Hz}, 2 \mathrm{H}) .{ }^{13} \mathrm{C}$ NMR $\left(151 \mathrm{MHz}\right.$, DMSO- $\left.d_{6}\right) \delta 175.1,153.7,129.2$, $128.3,120.4,120.2,108.9,108.7,51.4,50.7,41.0,28.1$.

(v) (trans)-4-(1,2-Dihydro-2-oxobenzo[d]imidazol-3-yl)cyclohexanecarbohydrazide (31b). To a mixture of (trans)-methyl 4-(1,2-dihydro-2-oxobenzo[d]imidazol-3-yl)cyclohexanecarboxylate (30b) (500 $\mathrm{mg}, 1.82 \mathrm{mmol}$ ) in ethanol was added hydrazine hydrate, and the mixture was heated at $120{ }^{\circ} \mathrm{C}$ for $3 \mathrm{~h}$ under microwave irradiation in a sealed vial (Biotage initiator ${ }^{+}$). Upon completion of reaction, the solvent was removed under reduced pressure and the crude solid was washed with a mixture of dichloromethane and methanol to yield (trans)-4-(1,2-dihydro-2-oxobenzo[d]imidazol-3yl)cyclohexanecarbohydrazide (31b) as a solid powder which was used in the next reaction step without further purification. Yield: 460 mg (92\%). Mp $273{ }^{\circ} \mathrm{C}$ (decomposition). HRMS for $\mathrm{C}_{14} \mathrm{H}_{18} \mathrm{~N}_{4} \mathrm{O}_{2}+$ $\mathrm{H}^{+},[\mathrm{M}+\mathrm{H}]^{+} \mathrm{m} / z$, calcd 275.1503 , found 275.1511 .

(vi) 1-((trans)-4-(4-(2-Chlorophenyl)-5-(pyrimidin-4-yl)-4H-1,2,4triazol-3-yl)cyclohexyl)-1H-benzo[d]imidazol-2(3H)-one (15a). The (trans)-4-(1,2-dihydro-2-oxobenzo[d]imidazol-3-yl)cyclohexanecarbohydrazide (31b) $(200 \mathrm{mg}, 0.729 \mathrm{mmol})$ was added to a solution of methyl (Z)-N-(2-chlorophenyl)pyrimidine-4-carbimidothioate (26) $(211 \mathrm{mg}, 0.801 \mathrm{mmol})$ in $N, N$-dimethylacetamide $(1 \mathrm{~mL})$. Trifluoroacetic acid $(27.8 \mu \mathrm{L})$ was added, and the reaction mixture was heated at $120{ }^{\circ} \mathrm{C}$ for $14 \mathrm{~h}$. After cooling down to room temperature, the reaction mixture was filtered and the residue washed with dichloromethane and methanol. The filtrate was concentrated under reduced pressure to remove the methanol and dichloromethane. A mixture of water and dichloromethane was added, and the reaction mixture portioned using a separating funnel. The organic layer was washed with water, brine, dried over magnesium sulfate, filtered, and concentrated under reduced pressure. The crude product was purified by chromatography on silica gel, eluting with a gradient of dichloromethane/methanol. The fractions containing the product were combined and the solvent was evaporated under reduced pressure to yield the title compound $\mathbf{1 5 a}$ as a white solid. Yield: $72 \mathrm{mg}$ (21\%). Mp 274-276 ${ }^{\circ} \mathrm{C}$. HRMS for $\mathrm{C}_{25} \mathrm{H}_{22} \mathrm{ClN}_{7} \mathrm{O}+\mathrm{H}^{+},[\mathrm{M}+\mathrm{H}]^{+}$ $m / z$, calcd 472.1647 , found 472.1654. ${ }^{1} \mathrm{H}$ NMR $(600 \mathrm{MHz}$, DMSO$\left.d_{6}\right) \delta 10.87(\mathrm{~s}, 1 \mathrm{H}), 9.00(\mathrm{~d}, J=5.3 \mathrm{~Hz}, 1 \mathrm{H}), 8.93(\mathrm{~d}, J=1.4 \mathrm{~Hz}, 1 \mathrm{H})$, $8.27(\mathrm{dd}, J=5.3,1.4 \mathrm{~Hz}, 1 \mathrm{H}), 7.86(\mathrm{dd}, J=7.8,1.7 \mathrm{~Hz}, 1 \mathrm{H}), 7.81(\mathrm{dd}$, $J=8.0,1.4 \mathrm{~Hz}, 1 \mathrm{H}), 7.72(\mathrm{td}, J=7.8,1.7 \mathrm{~Hz}, 1 \mathrm{H}), 7.67(\mathrm{td}, J=7.6,1.5$ $\mathrm{Hz}, 1 \mathrm{H}), 7.35(\mathrm{td}, J=4.7,4.1,2.2 \mathrm{~Hz}, 1 \mathrm{H}), 7.01(\mathrm{~d}, J=2.7 \mathrm{~Hz}, 3 \mathrm{H})$, $4.29(\mathrm{tt}, J=12.2,3.9 \mathrm{~Hz}, 1 \mathrm{H}), 2.62(\mathrm{tdd}, J=11.9,7.3,3.7 \mathrm{~Hz}, 1 \mathrm{H})$, 2.19 (dtd, $J=30.7,14.8,13.9,3.5 \mathrm{~Hz}, 3 \mathrm{H}), 2.02-1.90(\mathrm{~m}, 3 \mathrm{H}), 1.81$ (ddd, $J=15.6,8.8,2.9 \mathrm{~Hz}, 2 \mathrm{H}) .{ }^{13} \mathrm{C}$ NMR $\left(151 \mathrm{MHz}, \mathrm{DMSO}-d_{6}\right) \delta$ $160.1,158.3,158.0,153.7,153.2,150.0,132.5,131.6,131.0,130.1$, $129.8,129.4,128.5,128.2,120.4,120.2,118.9,108.7,108.6,50.8,32.7$, 30.6, 30.1, 28.5.

Preparation of 1-((trans)-4-(-4-(2-Chlorophenyl)-5-(pyrimidin-4-yl)-4H-1,2,4-triazol-3-yl)cyclohexyl)-2,3-dihydro-2-oxo$1 \mathrm{H}$-benzo[d]imidazole-5-carbonitrile (15). (i) (trans)-Methyl 4(4-Cyano-2-nitrophenylamino)cyclohexanecarboxylate (29a). To a solution of methyl 4-aminocyclohexanecarboxylate hydrochloride (27a) (1.5 g, $7.74 \mathrm{mmol}$ ) and 4-fluoro-3-nitrobenzonitrile (28a) $(1.28 \mathrm{~g}, 7.74 \mathrm{mmol})$ in acetonitrile $(50 \mathrm{~mL})$ was added $N, N$ diisopropylethylamine $(2.69 \mathrm{~mL}, 15.49 \mathrm{mmol})$ at room temperature. The resulting reaction mixture was stirred for $18 \mathrm{~h}$ at room temperature. Acetonitrile was removed under reduced pressure, and the crude solid was dissolved in dichloromethane, and the dichloromethane layer was washed with water, dried over magnesium sulfate, filtered, and then concentrated under reduced pressure. The crude solid (trans)-methyl 4-(4-cyano-2-nitrophenylamino)cyclohexanecarboxylate (29a) was washed with cold methanol and used in the next step without any further purification. Yield $1.8 \mathrm{~g}$ (77\%). Mp 138$140{ }^{\circ} \mathrm{C}$. HRMS for $\mathrm{C}_{15} \mathrm{H}_{17} \mathrm{~N}_{3} \mathrm{O}_{4}+\mathrm{H}^{+},[\mathrm{M}+\mathrm{H}]^{+} \mathrm{m} / z$, calcd $=$ 304.1292, found 304.1307. ${ }^{1} \mathrm{H}$ NMR $\left(600 \mathrm{MHz}\right.$, DMSO- $\left.d_{6}\right) \delta 8.49(\mathrm{~d}$, $J=2.1 \mathrm{~Hz}, 1 \mathrm{H}), 8.20(\mathrm{~d}, J=7.9 \mathrm{~Hz}, 1 \mathrm{H}), 7.81(\mathrm{dd}, J=9.1,2.1 \mathrm{~Hz}$ $1 \mathrm{H}), 7.30(\mathrm{~d}, J=9.2 \mathrm{~Hz}, 1 \mathrm{H}), 3.72(\mathrm{tdt}, J=11.3,7.8,3.9 \mathrm{~Hz}, 1 \mathrm{H})$, $3.61(\mathrm{~s}, 3 \mathrm{H}), 2.35(\mathrm{tt}, J=11.9,3.6 \mathrm{~Hz}, 1 \mathrm{H}), 2.05-1.99(\mathrm{~m}, 2 \mathrm{H}), 1.98-$ $1.92(\mathrm{~m}, 2 \mathrm{H}), 1.56(\mathrm{qd}, J=13.0,3.1 \mathrm{~Hz}, 2 \mathrm{H}), 1.49-1.41(\mathrm{~m}, 2 \mathrm{H}) .{ }^{13} \mathrm{C}$ NMR $\left(151 \mathrm{MHz}, \mathrm{DMSO}-d_{6}\right) \delta 175.0,146.0,137.7,132.0,130.6$, 118.2, 116.1, 96.5, 51.4, 50.3, 41.2, 30.6, 27.1.

(ii) (trans)-Methyl 4-(6-Cyano-1,2-dihydro-2-oxobenzo[d]imidazol-3-yl)cyclohexanecarboxylate (30a). A reaction flask with a mixture of (trans)-methyl 4-(4-cyano-2-nitrophenylamino)cyclohexanecarboxylate (29a) $(2.38 \mathrm{~g}, 7.85 \mathrm{mmol})$ and a catalytic amount of $10 \%$ palladium on charcoal in ethanol $(450 \mathrm{~mL})$ was equipped with a hydrogen balloon, and hydrogen was gas bubbled through the reaction mixture at atmospheric pressure. After $2 \mathrm{~h}$, the balloon was removed and the reaction mixture purged with nitrogen, filtered through a pad of Celite, and washed twice with ethanol. Then the filtrate was concentrated under reduced pressure to afford (trans)methyl 4-(2-amino-4-cyanophenylamino)cyclohexanecarboxylate as an amorphous solid. Yield: $1.84 \mathrm{~g}(86 \%)$. HRMS for $\mathrm{C}_{15} \mathrm{H}_{19} \mathrm{~N}_{3} \mathrm{O}_{2}+\mathrm{H}^{+}$, $[\mathrm{M}+\mathrm{H}]^{+} \mathrm{m} / z$, calcd 274.1550 , found $274.1553 .{ }^{1} \mathrm{H}$ NMR $(600 \mathrm{MHz}$, DMSO- $\left.d_{6}\right) \delta 6.89(\mathrm{~d}, J=8.8 \mathrm{~Hz}, 1 \mathrm{H}), 6.75(\mathrm{~d}, J=9.7 \mathrm{~Hz}, 1 \mathrm{H}), 6.51$ $(\mathrm{t}, J=9.8 \mathrm{~Hz}, 1 \mathrm{H}), 5.09(\mathrm{~d}, J=8.5 \mathrm{~Hz}, 1 \mathrm{H}), 4.97(\mathrm{~s}, 2 \mathrm{H}), 3.59(\mathrm{q}, J=$ $12.0 \mathrm{~Hz}, 3 \mathrm{H}), 2.32(\mathrm{q}, J=11.2,10.0 \mathrm{~Hz}, 1 \mathrm{H}), 2.04-1.97(\mathrm{~m}, 2 \mathrm{H})$, $1.93(\mathrm{t}, J=11.3 \mathrm{~Hz}, 2 \mathrm{H}), 1.49(\mathrm{dt}, J=22.1,12.1 \mathrm{~Hz}, 2 \mathrm{H}), 1.23(\mathrm{dt}, J=$ 
22.3, $12.1 \mathrm{~Hz}, 2 \mathrm{H}) .{ }^{13} \mathrm{C}$ NMR (151 MHz, DMSO-d $\left.d_{6}\right) \delta 175.2,138.8$, 135.0, 122.7, 121.1, 115.1, 108.9, 96.1, 51.3, 50.0, 41.8, 31.3, 27.5. To a mixture of (trans)-methyl 4-(2-amino-4-cyanophenylamino)cyclohexanecarboxylate $(1.87 \mathrm{~g}, 6.84 \mathrm{mmol})$ in dichloromethane $(65$ $\mathrm{mL}$ ) was added triphosgene $\left(3.06 \mathrm{~g}, 10.31 \mathrm{mmol}\right.$ ) at $0{ }^{\circ} \mathrm{C}$ (ice water bath). The mixture was stirred at $0{ }^{\circ} \mathrm{C}$ for $1 \mathrm{~h}$. Then it was allowed to warm to room temperature and stirred for $24 \mathrm{~h}$. Next the resulting mixture was heated to reflux for $24 \mathrm{~h}$. The reaction mixture was diluted with dichloromethane and washed with saturated sodium bicarbonate and brine, dried over magnesium sulfate, and evaporated to give (trans)-methyl 4-(6-cyano-1,2-dihydro-2-oxobenzo[d]imidazol-3-yl)cyclohexanecarboxylate (30a) as a glassy solid. Yield: $1.90 \mathrm{~g}$ (93\%). HRMS for $\mathrm{C}_{16} \mathrm{H}_{17} \mathrm{~N}_{3} \mathrm{O}_{3}+\mathrm{H}^{+},[\mathrm{M}+\mathrm{H}]^{+} \mathrm{m} / z$, calcd 300.1343 , found 300.1356. ${ }^{1} \mathrm{H}$ NMR $\left(600 \mathrm{MHz}, \mathrm{DMSO}-d_{6}\right) \delta 11.30(\mathrm{~s}, 1 \mathrm{H}), 7.53(\mathrm{~d}, J$ $=8.3 \mathrm{~Hz}, 1 \mathrm{H}), 7.44(\mathrm{dd}, J=8.3,1.6 \mathrm{~Hz}, 1 \mathrm{H}), 7.35(\mathrm{~d}, J=1.6 \mathrm{~Hz}, 1 \mathrm{H})$, $4.20(\mathrm{tt}, J=12.4,4.0 \mathrm{~Hz}, 1 \mathrm{H}), 3.62(\mathrm{~s}, 3 \mathrm{H}), 2.20(\mathrm{qd}, J=13.0,3.7 \mathrm{~Hz}$, $2 \mathrm{H}), 2.03$ (ddd, $J=11.9,5.0,2.8 \mathrm{~Hz}, 2 \mathrm{H}), 1.74(\mathrm{dt}, J=13.4,3.7 \mathrm{~Hz}$, $2 \mathrm{H}), 1.53(\mathrm{qd}, J=13.2,3.5 \mathrm{~Hz}, 2 \mathrm{H}) .{ }^{13} \mathrm{C}$ NMR $\left(151 \mathrm{MHz}\right.$, DMSO- $\left.d_{6}\right)$ $\delta$ 175.1, 153.6, 133.0, 128.6, 125.5, 119.7, 111.5, 109.5, 102.3, 51.4, 51.2, 40.9, 28.0, 27.9.

(iii) (trans)-4-(6-Cyano-1,2-dihydro-2-oxobenzo[d]imidazol-3-yl)cyclohexanecarbohydrazide (31a). To a mixture of (trans)-methyl 4(6-cyano-1,2-dihydro-2-oxobenzo[d]imidazol-3-yl)cyclohexanecarboxylate (30a) $(299.3 \mathrm{mg}, 1.00 \mathrm{mmol})$ in ethanol $(7 \mathrm{~mL})$ was added hydrazine hydrate $(7 \mathrm{~mL})$, and the mixture was heated to $80^{\circ} \mathrm{C}$ for $3 \mathrm{~h}$ under microwave irradiation in a sealed vial (Biotage initiator + ). Upon completion of reaction, the reaction mixture was filtered and the crude solid was washed with methanol, filtered, and dried to afford (trans)-3-(1,2-dihydro-2-oxobenzo[d]imidazol-3-yl)cyclobutanecarbohydrazide (31a) as a white solid. Yield: $269 \mathrm{mg}$ (90\%). Mp 348 ${ }^{\circ} \mathrm{C}$ (decomposition). HRMS for $\mathrm{C}_{15} \mathrm{H}_{17} \mathrm{~N}_{5} \mathrm{O}_{2}+\mathrm{H}^{+},[\mathrm{M}+\mathrm{H}]^{+} \mathrm{m} / z$, calcd 300.1455, found 300.1466.

(iv) 1-((trans)-4-(-4-(2-Chlorophenyl)-5-(pyrimidin-4-yl)-4H-1,2,4triazol-3-yl)cyclohexyl)-2,3-dihydro-2-oxo-1H-benzo[d]imidazole-5carbonitrile (15). (trans)-4-(6-Cyano-1,2-dihydro-2-oxobenzo[d]imidazol-3-yl)cyclohexanecarbohydrazide (31a) (142 mg, 0.47 mmol) was added to a solution of methyl (Z)-N-(2-chlorophenyl)pyrimidine-4-carbimidothioate $(26)(138 \mathrm{mg}, 0.52 \mathrm{mmol})$ in $N, N$ dimethylacetamide $(2 \mathrm{~mL})$. Trifluoroacetic acid $(18.2 \mu \mathrm{L}, 0.23 \mathrm{mmol})$ was added, and the reaction mixture was heated at $120{ }^{\circ} \mathrm{C}$ for $14 \mathrm{~h}$. The reaction mixture was then cooled down to room temperature and filtered. Water was added to the filtrate, and the reaction mixture was extracted with dichloromethane. The combined organic layers were washed with water, brine, dried over magnesium sulfate, filtered, and concentrated under reduced pressure. The crude solid was then washed with an acetonitrile/water mixture $(1: 1,3 \mathrm{~mL})$ followed by cold methanol to afford compound 1-((trans)-4-(4-(2-chlorophenyl)5-(pyrimidin-4-yl)-4H-1,2,4-triazol-3-yl)cyclohexyl)-2,3-dihydro-2oxo-1H-benzo[d]imidazole-5-carbonitrile $(15)$ as a light yellow solid. Yield: $24 \mathrm{mg}$ (10\%). Mp $267{ }^{\circ} \mathrm{C}$. HRMS for $\mathrm{C}_{26} \mathrm{H}_{21} \mathrm{ClN}_{8} \mathrm{O},+\mathrm{H}^{+}$, [M $+\mathrm{H}]^{+} \mathrm{m} / z$, calcd $=497.1600$, found 497.1609. ${ }^{1} \mathrm{H}$ NMR $(600 \mathrm{MHz}$, DMSO- $\left.d_{6}\right) \delta 11.44(\mathrm{~s}, 1 \mathrm{H}), 9.08(\mathrm{~d}, J=5.3 \mathrm{~Hz}, 1 \mathrm{H}), 9.01(\mathrm{~d}, J=1.4$ $\mathrm{Hz}, 1 \mathrm{H}), 8.34(\mathrm{dd}, J=5.3,1.4 \mathrm{~Hz}, 1 \mathrm{H}), 7.93(\mathrm{dd}, J=7.8,1.7 \mathrm{~Hz}, 1 \mathrm{H})$, $7.89(\mathrm{dd}, J=8.1,1.4 \mathrm{~Hz}, 1 \mathrm{H}), 7.80(\mathrm{td}, J=7.8,1.7 \mathrm{~Hz}, 1 \mathrm{H}), 7.75(\mathrm{td}, J$ $=7.7,1.5 \mathrm{~Hz}, 1 \mathrm{H}), 7.67(\mathrm{~d}, J=8.3 \mathrm{~Hz}, 1 \mathrm{H}), 7.58(\mathrm{dd}, J=8.2,1.6 \mathrm{~Hz}$, $1 \mathrm{H}), 7.48(\mathrm{~d}, J=1.5 \mathrm{~Hz}, 1 \mathrm{H}), 4.43(\mathrm{tt}, J=12.3,3.9 \mathrm{~Hz}, 1 \mathrm{H}), 2.73-$ $2.66(\mathrm{~m}, 1 \mathrm{H}), 2.31-2.19(\mathrm{~m}, 3 \mathrm{H}), 2.10-1.98(\mathrm{~m}, 3 \mathrm{H}), 1.95-1.85(\mathrm{~m}$, $2 \mathrm{H}) .{ }^{13} \mathrm{C}$ NMR $\left(151 \mathrm{MHz}, \mathrm{DMSO}-d_{6}\right) \delta 160.0,158.3,158.0,153.6$, $153.2,150.0,133.2,132.5,131.6,131.0,130.1,129.8,128.5,128.4$, 125.5, 119.7, 118.9, 111.4, 109.4, 102.3, 51.3, 32.6, 30.5, 30.0, 28.2.

Preparation of 1-((trans)-3-(-4-(2-chlorophenyl)-5-(pyrimidin-4-yl)-4H-1,2,4-triazol-3-yl)cyclobutyl)- $1 H$-benzo[d]imidazol-2(3H)-one (16a). (i) (trans)-Methyl 3-(2Nitrophenylamino)cyclobutanecarboxylate (29d). To a solution of (trans)-methyl 3-aminocyclobutanecarboxylate hydrochloride (27b) $(1.0 \mathrm{~g}, 6.05 \mathrm{mmol})$ and 1-fluoro-2-nitrobenzene $(\mathbf{2 8 b})(1.09 \mathrm{~g}, 7.74$ $\mathrm{mmol})$ in acetonitrile $(50 \mathrm{~mL})$ was added potassium carbonate $(1.60$ $\mathrm{g}, 11.6 \mathrm{mmol}$ ) at ambient temperature. The resulting reaction mixture was heated for $16 \mathrm{~h}$ at reflux. Acetonitrile was removed under reduced pressure, and the crude solid was dissolved in dichloromethane, and the dichloromethane layer was washed with water, dried over magnesium sulfate, and then concentrated under reduced pressure. Unreacted 1-fluoro-2-nitrobenzene was removed by co-distillation with toluene. The crude product was purified by chromatography on silica gel, eluting with a gradient of cyclohexane/ethyl acetate. The fractions containing the product were combined and the solvent was evaporated under reduced pressure to yield $1.43 \mathrm{~g}$ of (trans)-methyl-(2nitrophenylamino)cyclobutanecarboxylate $(\mathbf{2 9 d})$ as a greasy solid. Yield: $1.43 \mathrm{~g}(95 \%)$. HRMS for $\mathrm{C}_{12} \mathrm{H}_{14} \mathrm{~N}_{2} \mathrm{O}_{4}+\mathrm{H}^{+},[\mathrm{M}+\mathrm{H}]^{+} \mathrm{m} / z$, calcd 251.1026, found 251.1044. ${ }^{1} \mathrm{H}$ NMR $\left(300 \mathrm{MHz}\right.$, DMSO- $\left.d_{6}\right) \delta$ $8.10-8.04(\mathrm{~m}, 1 \mathrm{H}), 8.01(\mathrm{~d}, J=5.8 \mathrm{~Hz}, 1 \mathrm{H}), 7.53$ (ddd, $J=8.7,6.9$, $1.9 \mathrm{~Hz}, 1 \mathrm{H}), 6.81(\mathrm{~d}, J=8.7 \mathrm{~Hz}, 1 \mathrm{H}), 6.79-6.67(\mathrm{~m}, 1 \mathrm{H}), 4.24(\mathrm{~h}, J=$ $7.1 \mathrm{~Hz}, 1 \mathrm{H}), 3.66(\mathrm{~s}, 3 \mathrm{H}), 3.18(\mathrm{tt}, J=9.6,4.4 \mathrm{~Hz}, 1 \mathrm{H}), 2.75-2.60(\mathrm{~m}$, $2 \mathrm{H}), 2.34(\mathrm{dtd}, J=12.9,6.9,2.5 \mathrm{~Hz}, 2 \mathrm{H}) .{ }^{13} \mathrm{C}$ NMR $(75 \mathrm{MHz}$, DMSO- $\left.d_{6}\right) \delta 175.3,143.7,136.7,131.4,126.2,115.9,114.9,51.7,45.5$, $32.3,32.2$.

(ii) (trans)-Methyl 3-(1,2-Dihydro-2-oxobenzo[d]imidazol-3-yl)cyclobutanecarboxylate (30d). A reaction flask with a mixture of (trans)-methyl 3-(2-nitrophenylamino)cyclobutanecarboxylate (29d) $(1.4 \mathrm{~g}, 5.59 \mathrm{mmol})$ and a catalytic amount of $10 \%$ palladium on charcoal in ethanol was equipped with a hydrogen balloon, and hydrogen gas was bubbled through the reaction mixture at atmospheric pressure. After $2 \mathrm{~h}$, the balloon was removed and the reaction mixture purged with nitrogen, filtered through a pad of Celite, and washed twice with ethanol. The filtrate was concentrated under reduced pressure to afford (trans)-methyl-3-(2-aminophenylamino)cyclobutanecarboxylate as a solid. The crude product was used in the next step without any further purification. Yield: $936 \mathrm{mg}(76 \%)$. HRMS for $\mathrm{C}_{12} \mathrm{H}_{16} \mathrm{~N}_{2} \mathrm{O}_{2}+\mathrm{H}^{+}$, $[\mathrm{M}+\mathrm{H}]^{+} m / z$, calcd 221.1285, found 221.1286. ${ }^{1} \mathrm{H}$ NMR $\left(600 \mathrm{MHz}, \mathrm{DMSO}-d_{6}\right) \delta 6.53(\mathrm{~d}, J=6.8 \mathrm{~Hz}, 1 \mathrm{H})$, $6.44(\mathrm{dt}, J=19.4,7.2 \mathrm{~Hz}, 2 \mathrm{H}), 6.21(\mathrm{~d}, J=7.5 \mathrm{~Hz}, 1 \mathrm{H}), 4.71(\mathrm{~d}, J=$ $6.5 \mathrm{~Hz}, 1 \mathrm{H}), 4.50(\mathrm{~s}, 2 \mathrm{H}), 3.93(\mathrm{q}, J=6.9 \mathrm{~Hz}, 1 \mathrm{H}), 3.65(\mathrm{~s}, 3 \mathrm{H}), 3.14$ $(\mathrm{dt}, J=9.8,5.1 \mathrm{~Hz}, 1 \mathrm{H}), 2.56(\mathrm{ddd}, J=12.5,7.4,4.3 \mathrm{~Hz}, 2 \mathrm{H}), 2.15$ (ddd, $J=12.6,9.5,6.0 \mathrm{~Hz}, 2 \mathrm{H}) .{ }^{13} \mathrm{C}$ NMR $\left(151 \mathrm{MHz}\right.$, DMSO- $\left.d_{6}\right) \delta$ $175.7,135.5,134.3,117.4,114.0,110.5,51.5,46.3,32.6,32.5$. Tо а mixture of (trans)-methyl-3-(2-aminophenylamino)cyclobutanecarboxylate $(1.12 \mathrm{~g}, 5.08 \mathrm{mmol})$ in dichloromethane was added triphosgene $(2.26 \mathrm{~g}, 7.63 \mathrm{mmol})$ at $0{ }^{\circ} \mathrm{C}$ (ice water bath). The mixture was stirred at $0{ }^{\circ} \mathrm{C}$ for $1 \mathrm{~h}$. Then it was allowed to warm to room temperature and stirred for $24 \mathrm{~h}$. Next the resulting mixture was refluxed for $24 \mathrm{~h}$. The reaction mixture was diluted with dichloromethane and washed with saturated sodium bicarbonate and brine, dried over magnesium sulfate, and evaporated under reduced pressure to give (trans)-methyl-3-(1,2-dihydro-2-oxobenzo[d]imidazol-3-yl)cyclobutanecarboxylate (30d) as a white foam. Yield: $1.15 \mathrm{~g}$ (92\%). HRMS for $\mathrm{C}_{13} \mathrm{H}_{14} \mathrm{~N}_{2} \mathrm{O}_{3}+\mathrm{H}^{+}$, $[\mathrm{M}+\mathrm{H}]^{+} \mathrm{m} / z$, calcd 247.1077, found 247.1076. ${ }^{1} \mathrm{H}$ NMR (300 MHz, $\left.\mathrm{CDCl}_{3}\right) \delta 10.60(\mathrm{~s}, 1 \mathrm{H}), 7.22-7.04$ (m, 4H), 5.36-5.03 (m, $1 \mathrm{H}), 3.80(\mathrm{~s}, 3 \mathrm{H}), 3.33(\mathrm{q}, J=7.5 \mathrm{~Hz}, 3 \mathrm{H})$, $2.82-2.65(\mathrm{~m}, 2 \mathrm{H}) .{ }^{13} \mathrm{C}$ NMR $\left(75 \mathrm{MHz}, \mathrm{CDCl}_{3}\right) \delta 176.0,155.5$, 129.3, 128.0, 121.4, 121.0, 109.9, 108.3, 52.0, 45.3, 32.3, 30.3.

(iii) (trans)-3-(1,2-Dihydro-2-oxobenzo[d]imidazol-3-yl)cyclobutanecarbohydrazide (31d). To a mixture of (trans)-methyl3-(1,2-dihydro-2-oxobenzo[d]imidazol-3-yl)cyclobutanecarboxylate (30d) $(400 \mathrm{mg}, 1.62 \mathrm{mmol})$ in ethanol $(7 \mathrm{~mL})$ was added hydrazine hydrate $(7 \mathrm{~mL})$, and the mixture was heated to $100{ }^{\circ} \mathrm{C}$ for $3 \mathrm{~h}$ under microwave irradiation in a sealed vial (Biotage initiator $\left.{ }^{+}\right)$. Upon completion of reaction, the solvent was removed under reduced pressure and the crude solid was washed with methanol, resulting in (trans)-3-(1,2-dihydro-2-oxobenzo[d]imidazol-3-yl)cyclobutanecarbohydrazide (31d) as a solid product which was used in the next step without any further purification. Yield: $360 \mathrm{mg}$ (90\%). Mp >250 ${ }^{\circ} \mathrm{C}$ (decomposition). HRMS for $\mathrm{C}_{12} \mathrm{H}_{14} \mathrm{~N}_{4} \mathrm{O}_{2}+\mathrm{H}^{+},[\mathrm{M}+\mathrm{H}]^{+} \mathrm{m} / z$, calcd 247.1190, found 247.1202 .

(iv) 1-((trans)-3-(-4-(2-Chlorophenyl)-5-(pyrimidin-4-yl)-4H-1,2,4triazol-3-yl)cyclobutyl)-1H-benzo[d]imidazol-2(3H)-one (16a). (trans)-3-(1,2-Dihydro-2-oxobenzo[d]imidazol-3-yl)cyclobutanecarbohydrazide (31d) $(123 \mathrm{mg}, 0.5 \mathrm{mmol})$ was added to a solution of methyl (Z)-N-(2-chlorophenyl)pyrimidine-4-carbimidothioate (26) $(158 \mathrm{mg}, 0.6 \mathrm{mmol})$ in $N, N$-dimethylacetamide $(1 \mathrm{~mL})$. Trifluoroacetic acid $(19 \mu \mathrm{L}, 0.25 \mathrm{mmol})$ was added, and the reaction mixture 
was heated to $120{ }^{\circ} \mathrm{C}$ for $14 \mathrm{~h}$. Water was added, and the reaction mixture was extracted with dichloromethane. The organic layer was washed with water, brine, dried over magnesium sulfate, filtered, and concentrated. The crude solid was purified by preparative HPLC (C18 reverse phase column, elution with a water/MeCN gradient with $0.1 \%$ TFA). The fractions containing the product were evaporated and lyophilized to yield 1-((trans)-3-(4-(2-chlorophenyl)-5-(pyrimidin-4yl)-4H-1,2,4-triazol-3-yl)cyclobutyl)-1H-benzo[d]imidazol-2(3H)-one (16a) as a white solid. The product was obtained as its trifluoroacetate salt. Yield: $46 \mathrm{mg}(16 \%)$. Mp $160{ }^{\circ} \mathrm{C}$. HRMS for $\mathrm{C}_{23} \mathrm{H}_{18} \mathrm{ClN}_{7} \mathrm{O}+\mathrm{H}^{+}$, $[\mathrm{M}+\mathrm{H}]^{+} \mathrm{m} / z$, calcd 444.1334, found 444.1342. ${ }^{1} \mathrm{H}$ NMR $(600 \mathrm{MHz}$, $\left.\mathrm{CDCl}_{3}\right) \delta 9.41(\mathrm{~s}, 1 \mathrm{H}), 8.87-8.84(\mathrm{~m}, 2 \mathrm{H}), 8.33(\mathrm{dd}, J=5.3,1.4 \mathrm{~Hz}$, $1 \mathrm{H}), 7.58(\mathrm{dd}, J=8.1,1.5 \mathrm{~Hz}, 1 \mathrm{H}), 7.53(\mathrm{td}, J=7.8,1.6 \mathrm{~Hz}, 1 \mathrm{H}), 7.47$ $(\mathrm{td}, J=7.7,1.6 \mathrm{~Hz}, 1 \mathrm{H}), 7.34(\mathrm{dd}, J=7.9,1.6 \mathrm{~Hz}, 1 \mathrm{H}), 7.17(\mathrm{~d}, J=7.8$ $\mathrm{Hz}, 1 \mathrm{H}), 7.13(\mathrm{dt}, J=7.8,4.2 \mathrm{~Hz}, 1 \mathrm{H}), 7.10(\mathrm{dd}, J=4.0,0.9 \mathrm{~Hz}, 2 \mathrm{H})$, 5.40-5.24 (m, $1 \mathrm{H}), 3.50-3.41(\mathrm{~m}, 2 \mathrm{H}), 3.41-3.34(\mathrm{~m}, 1 \mathrm{H}), 3.01-$ $2.96(\mathrm{~m}, 1 \mathrm{H}), 2.95-2.90(\mathrm{~m}, 1 \mathrm{H}) .{ }^{13} \mathrm{C}$ NMR $\left(151 \mathrm{MHz}, \mathrm{DMSO}-d_{6}\right) \delta$ 159.6, 158.4, 158.1, 153.7, 153.1, 150.7, 132.6, 131.5, 130.8, 130.0, $129.7,129.1,128.5,128.2,120.8,120.5,118.9,108.8,108.6,44.0,31.2$, 30.6, 23.6.

Preparation of 1-((trans)-3-(4-(2-Chlorophenyl)-5-(pyrimidin-4-yl)-4H-1,2,4-triazol-3-yl)cyclobutyl)-2,3-dihydro-2-oxo$1 \mathrm{H}$-benzo[d] imidazole-5-carbonitrile (16). (i) (trans)-Methyl 3(4-Cyano-2-nitrophenylamino)cyclobutanecarboxylate (29c). To a solution of (trans)-methyl 3-aminocyclobutanecarboxylate hydrochloride $(\mathbf{2 7 b})(331.2 \mathrm{mg}, 2.0 \mathrm{mmol})$ and 4-fluoro-3-nitrobenzonitrile (28a) $(332 \mathrm{mg}, 2.0 \mathrm{mmol})$ in acetonitrile $(4 \mathrm{~mL})$ was added $N, N$ diisopropylethylamine $(1.04 \mathrm{~mL}, 6.0 \mathrm{mmol})$ at ambient temperature. The resulting reaction mixture was stirred for $24 \mathrm{~h}$ at room temperature. After completion of the reaction, the acetonitrile was removed under reduced pressure and the crude solid was dissolved in dichloromethane. The dichloromethane layer was washed twice with water, brine, dried over magnesium sulfate, concentrated under reduced pressure and the precipitated product washed with cold methanol to yield (trans)-methyl-3-(4-cyano-2-nitrophenylamino)cyclobutanecarboxylate $(29 \mathrm{c})$ as a light yellow solid. Yield: $318 \mathrm{mg}$ (96\%). Mp 127-131 ${ }^{\circ} \mathrm{C}$. HRMS for $\mathrm{C}_{13} \mathrm{H}_{13} \mathrm{~N}_{3} \mathrm{O}_{4}+\mathrm{H}^{+},[\mathrm{M}+\mathrm{H}]^{+} \mathrm{m} /$ $z$, calcd 276.0979, found 276.0992. ${ }^{1} \mathrm{H}$ NMR $\left(300 \mathrm{MHz}, \mathrm{CDCl}_{3}\right) \delta$ $8.53-8.42(\mathrm{~m}, 2 \mathrm{H}), 7.61(\mathrm{dd}, J=9.0,1.9 \mathrm{~Hz}, 1 \mathrm{H}), 6.77(\mathrm{~d}, J=9.0 \mathrm{~Hz}$, $1 \mathrm{H}), 4.38(\mathrm{~h}, J=7.3 \mathrm{~Hz}, 1 \mathrm{H}), 3.76(\mathrm{~s}, 3 \mathrm{H}), 3.22(\mathrm{td}, J=9.6,4.7 \mathrm{~Hz}$, $1 \mathrm{H}), 2.94-2.76(\mathrm{~m}, 2 \mathrm{H}), 2.37(\mathrm{dtd}, J=13.1,7.1,2.7 \mathrm{~Hz}, 2 \mathrm{H}) .{ }^{13} \mathrm{C}$ NMR $\left(75 \mathrm{MHz}, \mathrm{CDCl}_{3}\right) \delta 175.4,145.7,137.7,132.0,131.4,117.7$, $115.2,98.6,52.1,45.9,33.0,32.8$.

(ii) (trans)-Methyl 3-(6-Cyano-1,2-dihydro-2-oxobenzo[d]imidazol-3-yl)cyclobutanecarboxylate (30c). A reaction flask charged with a mixture of (trans)-methyl-3-(4-cyano-2-nitrophenylamino)cyclobutanecarboxylate $(29 \mathrm{c})(1.5 \mathrm{~g}, 5.45 \mathrm{mmol})$ and a catalytic amount of $10 \%$ palladium on charcoal in ethanol $(400 \mathrm{~mL})$ was equipped with a hydrogen balloon, and hydrogen gas was bubbled through the reaction mixture at atmospheric pressure. After $2 \mathrm{~h}$, the balloon was removed and the reaction mixture was purged with nitrogen, filtered through a pad of Celite, and washed twice with ethanol. The filtrate was concentrated under reduced pressure to afford (trans)-methyl-3-(2-amino-4-cyanophenylamino)cyclobutanecarboxylate as a greasy solid. Yield: $962 \mathrm{mg}$ (72\%). MS (ESI) for $\mathrm{C}_{13} \mathrm{H}_{15} \mathrm{~N}_{3} \mathrm{O}_{2}+\mathrm{H}^{+},[\mathrm{M}+\mathrm{H}]^{+} m / z$, calcd $=246.1$, found 246.2. To a mixture of (trans)-methyl-3-(2-amino-4-cyanophenylamino)cyclobutanecarboxylate $(1 \mathrm{~g}, 4.07 \mathrm{mmol})$ in dichloromethane $(60$ $\mathrm{mL})$ at $0{ }^{\circ} \mathrm{C}$ (ice-water bath) was added triphosgene $(1.8 \mathrm{~g}, 6.12$ $\mathrm{mmol}$ ). The mixture was stirred at $0{ }^{\circ} \mathrm{C}$ for $1 \mathrm{~h}$ and was then allowed to warm to room temperature and stirred for $24 \mathrm{~h}$. Next the resulting mixture was refluxed for $24 \mathrm{~h}$. The reaction mixture was diluted with dichloromethane and washed with saturated sodium bicarbonate and brine, dried over magnesium sulfate, and evaporated under reduced pressure to give (trans)-methyl-3-(6-cyano-1,2-dihydro-2-oxobenzo[d]imidazol-3-yl)cyclobutanecarboxylate (30c) as an amorphous solid. Yield: $1.05 \mathrm{~g}$ (95\%). MS (ESI) for $\mathrm{C}_{14} \mathrm{H}_{13} \mathrm{~N}_{3} \mathrm{O}_{3}+\mathrm{H}^{+},[\mathrm{M}+\mathrm{H}]^{+} \mathrm{m} / z$, calcd 272.1, found 272.2. ${ }^{1} \mathrm{H}$ NMR $\left(300 \mathrm{MHz}^{\mathrm{CDCl}}{ }_{3}\right) \delta 10.62(\mathrm{~s}$, $1 \mathrm{H}), 7.43(\mathrm{~d}, J=8.2 \mathrm{~Hz}, 2 \mathrm{H}), 7.21(\mathrm{~d}, J=8.2 \mathrm{~Hz}, 1 \mathrm{H}), 5.21-5.02(\mathrm{~m}$, $1 \mathrm{H}), 3.80(\mathrm{~s}, 3 \mathrm{H}), 3.30(\mathrm{td}, J=8.6,8.0,3.1 \mathrm{~Hz}, 3 \mathrm{H}), 2.84-2.63(\mathrm{~m}$,
$2 \mathrm{H}) .{ }^{13} \mathrm{C}$ NMR $\left(75 \mathrm{MHz}, \mathrm{CDCl}_{3}\right) \delta 175.8,155.4,132.9,127.9,126.2$, $119.2,112.9,108.7,104.6,52.2,45.9,32.3,30.3$.

(iii) (trans)-3-(5-Cyano-2-oxo-2,3-dihydro-1H-benzo[d]imidazol1-yl)cyclobutane-1-carbohydrazide (31c). To a mixture of (trans)methyl-3-(6-cyano-1,2-dihydro-2-oxobenzo[d]imidazol-3-yl)cyclobutanecarboxylate $(30 \mathrm{c})(360.0 \mathrm{mg}, 1.32 \mathrm{mmol})$ in methanol (7 $\mathrm{mL}$ ) was added hydrazine hydrate in ethanol $(7 \mathrm{~mL})$, and the mixture was stirred at $20{ }^{\circ} \mathrm{C}$ for $20 \mathrm{~h}$. Upon completion of reaction, the reaction mixture was filtered and the crude solid was washed with methanol, filtered, and dried to afford (trans)-3-(6-cyano-1,2-dihydro2-oxobenzo[d]imidazol-3-yl)cyclobutanecarbohydrazide (31c) as an amorphous powder. Yield: $230 \mathrm{mg}(64 \%)$. MS (ESI) for $\mathrm{C}_{13} \mathrm{H}_{13} \mathrm{~N}_{5} \mathrm{O}_{2}$, $+\mathrm{H}^{+},[\mathrm{M}+\mathrm{H}]^{+} \mathrm{m} / z$, calcd 272.1 , found 272.2.

(iv) 1-((trans)-3-(4-(2-Chlorophenyl)-5-(pyrimidin-4-yl)-4H-1,2,4triazol-3-yl)cyclobutyl)-2,3-dihydro-2-oxo-1H-benzo[d]imidazole-5carbonitrile (16). (trans)-3-(6-Cyano-1,2-dihydro-2-oxobenzo[d]imidazol-3-yl)cyclobutanecarbohydrazide (31c) $(68.5 \mathrm{mg}, 0.25$ mmol) was added to a solution of methyl (Z)-N-(2-chlorophenyl)pyrimidine-4-carbimidothioate (26) $(80 \mathrm{mg}, 0.30 \mathrm{mmol})$ in $\mathrm{N}, \mathrm{N}$ dimethylacetamide $(2 \mathrm{~mL})$. Trifluoroacetic acid $(9.6 \mu \mathrm{L}, 0.125 \mathrm{mmol})$ was added, and the reaction mixture was heated to $120{ }^{\circ} \mathrm{C}$ for $14 \mathrm{~h}$. Water was added, and the reaction mixture was extracted with ethyl acetate. The organic layer was washed with brine, dried over magnesium sulfate, and concentrated under reduced pressure. The crude solid was purified by preparative HPLC $\left(\mathrm{C}_{18}\right.$ reverse phase column, elution with a water/MeCN gradient with $0.1 \%$ TFA). The fractions containing the product were evaporated and lyophilized to yield 1-((trans)-3-(4-(2-chlorophenyl)-5-(pyrimidin-4-yl)-4H-1,2,4-triazol-3-yl)cyclobutyl)-2,3-dihydro-2-oxo- $1 H$-benzo [d] imidazole-5-carbonitrile (16) as a white solid. The product was obtained as its trifluoroacetate salt. Yield: $22.5 \mathrm{mg}$ (15\%). Mp 252-255 ${ }^{\circ} \mathrm{C}$. HRMS for $\mathrm{C}_{24} \mathrm{H}_{17} \mathrm{ClN}_{8} \mathrm{O}+\mathrm{H}^{+},[\mathrm{M}+\mathrm{H}]^{+} \mathrm{m} / z$, calcd 469.1287 , found 469.1275. ${ }^{1} \mathrm{H}$ NMR $\left(600 \mathrm{MHz}, \mathrm{DMSO}-d_{6}\right) \delta 11.37(\mathrm{~s}, 1 \mathrm{H}), 8.97(\mathrm{~d}, J$ $=5.2 \mathrm{~Hz}, 1 \mathrm{H}), 8.90(\mathrm{~s}, 1 \mathrm{H}), 8.25(\mathrm{~d}, J=5.0 \mathrm{~Hz}, 1 \mathrm{H}), 7.74(\mathrm{dd}, J=8.0$, $1.7 \mathrm{~Hz}, 2 \mathrm{H}), 7.63(\mathrm{td}, J=7.8,1.6 \mathrm{~Hz}, 1 \mathrm{H}), 7.57(\mathrm{dt}, J=7.6,3.5 \mathrm{~Hz}$, $2 \mathrm{H}), 7.45(\mathrm{dd}, J=8.3,1.6 \mathrm{~Hz}, 1 \mathrm{H}), 7.38(\mathrm{~s}, 1 \mathrm{H}), 5.27(\mathrm{p}, J=8.9 \mathrm{~Hz}$, $1 \mathrm{H}), 3.48(\mathrm{dq}, J=10.0,5.1,3.7 \mathrm{~Hz}, 1 \mathrm{H}), 3.10(\mathrm{q}, J=10.2 \mathrm{~Hz}, 2 \mathrm{H})$, 2.83 (ddt, $J=12.3,8.4,3.7 \mathrm{~Hz}, 1 \mathrm{H}), 2.73(\mathrm{ddt}, J=12.7,8.5,4.0 \mathrm{~Hz}$, $1 \mathrm{H}) .{ }^{13} \mathrm{C}$ NMR $\left(151 \mathrm{MHz}, \mathrm{DMSO}-d_{6}\right) \delta 160.0,158.9,158.6,154.2$, $153.6,151.2,133.5,133.1,132.0,131.3,130.5,130.2,129.0,128.9$, 126.2, 120.1, 119.4, 112.1, 109.8, 103.2, 44.9, 31.7, 31.1, 24.2.

\section{ASSOCIATED CONTENT}

\section{Supporting Information}

The Supporting Information is available free of charge on the ACS Publications website at DOI: 10.1021/acs.jmedchem.7b00883.

Experimental procedures for X-ray crystallography, biochemical and pharmacological characterization, and analytical data for all compounds (PDF)

Molecular formula strings and some data (CSV)

\section{Accession Codes}

Coordinates and structure factors are deposited at the Protein Data Bank with codes 5NSP (14) and 5NOB (16). The authors will release the atomic coordinates and experimental data upon article publication.

\section{AUTHOR INFORMATION}

\section{Corresponding Authors}

*S.K.: phone, +47 230790 17; e-mail, Stefan.KRAUSS@rrresearch.no.

*M.N.: phone, +49 30 9406-3083; e-mail, nazare@fmp-berlin. de.

\section{ORCID}

Lari Lehtiö: 0000-0001-7250-832X

Marc Nazaré: 0000-0002-1602-2330 


\section{Present Address}

U.R.A.: Research and Development, Amoli Organics Pvt. Ltd., ECP Canal Road, Taluka Padra District, Vadodara, India.

\section{Author Contributions}

The manuscript was written through contributions of all authors. All authors have given approval to the final version of the manuscript.

Notes

The authors declare no competing financial interest.

\section{ACKNOWLEDGMENTS}

Protein crystallography experiments were performed at the Diamond Light Source (Didcot, U.K.) on beamline I02 and at European Synchrotron Radiation Facility (ESRF, Grenoble, France) on beamline ID23-1. We are grateful to Local Contacts for providing assistance in using beamlines. The research leading to these results has received funding from the European Community's Seventh Framework Programme (FP7/20072013) under BioStruct-X (Grant Agreement No. 283570). The use of the facilities of the Biocenter Oulu Protein crystallography core facility, a member of Biocenter Finland and Instruct-FI, is gratefully acknowledged. The authors thank Bernd Rupp and Raed Al-Yamori (cheminformatics and software development) for the technical and scientific support in ChemAxon software deployment. The research was funded by Research Council of Norway "Extended biotarget validation studies for the specifc inhibitor of Wnt $\beta$-catenin signaling OD270", the Jane and Aatos Erkko Foundation, Sigrid Jusélius Foundation, Biocenter Oulu and Academy of Finland (Grants 287063 and 294085 for L.L.), and the Russian Ministry of Education and Science (Grant 14.N08.11.0056 for A.G.M. and S.L.).

\section{ABBREVIATIONS USED}

ARTD, ADP ribosyl transferase; AXIN, axis inhibition protein; $\mathrm{Balb} / \mathrm{c}$, Bagg albino/c; CLK2, CDC-like kinase 2; COLO320, colon adenocarcinoma cell line 320; EDCI, 1-ethyl-3-(3dimethylaminopropyl)carbodiimide; GRB, genomic regulatory block; IRAP, insulin-regulated aminopeptidase; MELK, maternal embryonic leucine zipper kinase; NuMA, nuclear mitotic apparatus; PARP, poly (ADP-ribose) polymerase; PRKG1, protein kinase G1; SAM, sterile $\alpha$ motif; ST-Luc/Ren, superTOP-luciferase/Renilla; SW480, human colon cancer cell line; TNKS, telomere-associated poly (ADP-ribose) polymerase tankyrase; TRF, telomere restriction fragment; TSF1, serine/threonine-protein kinase

\section{REFERENCES}

(1) Durkacz, B. W.; Irwin, J.; Shall, S. The Effect of Inhibition of (ADP-ribose)n Biosynthesis on DNA Repair Assayed by the Nucleoid Technique. Eur. J. Biochem. 1981, 121, 65-69.

(2) Durkacz, B. W.; Omidiji, O.; Gray, D. A.; Shall, S. (ADP-ribose)n Participates in DNA Excision Repair. Nature 1980, 283, 593-596.

(3) Rouleau, M.; Patel, A.; Hendzel, M. J.; Kaufmann, S. H.; Poirier, G. G. PARP Inhibition: PARP1 and Beyond. Nat. Rev. Cancer 2010, 10, 293-301.

(4) Purnell, M. R.; Whish, W. J. Novel Inhibitors of Poly(ADPribose) Synthetase. Biochem. J. 1980, 185, 775-777.

(5) Hottiger, M. O.; Hassa, P. O.; Lüscher, B.; Schüler, H.; KochNolte, F. Toward a Unified Nomenclature for Mammalian ADPRibosyltransferases. Trends Biochem. Sci. 2010, 35, 208-219.
(6) Haikarainen, T.; Krauss, S.; Lehtio, L. Tankyrases: Structure, Function and Therapeutic Implications in Cancer. Curr. Pharm. Des. 2014, 20, 6472-6488.

(7) Lehtiö, L.; Chi, N.-W.; Krauss, S. Tankyrases as Drug Targets. FEBS J. 2013, 280, 3576-3593.

(8) Riffell, J. L.; Lord, C. J.; Ashworth, A. Tankyrase-targeted Therapeutics: Expanding Opportunities in the PARP Family. Nat. Rev. Drug Discovery 2012, 11, 923-936.

(9) Guettler, S.; LaRose, J.; Petsalaki, E.; Gish, G.; Scotter, A.; Pawson, T.; Rottapel, R; Sicheri, F. Structural Basis and Sequence Rules for Substrate Recognition by Tankyrase Explain the Basis for Cherubism Disease. Cell 2011, 147, 1340-1354.

(10) Cook, B. D.; Dynek, J. N.; Chang, W.; Shostak, G.; Smith, S. Role for the Related Poly(ADP-Ribose) Polymerases Tankyrase 1 and 2 at Human Telomeres. Mol. Cell. Biol. 2002, 22, 332-342.

(11) Tanaka, N.; Mashima, T.; Mizutani, A.; Sato, A.; Aoyama, A.; Gong, B.; Yoshida, H.; Muramatsu, Y.; Nakata, K.; Matsuura, M.; Katayama, R.; Nagayama, S.; Fujita, N.; Sugimoto, Y.; Seimiya, H. APC Mutations as a Potential Biomarker for Sensitivity to Tankyrase Inhibitors in Colorectal Cancer. Mol. Cancer Ther. 2017, 16, 752-762.

(12) Lau, T.; Chan, E.; Callow, M.; Waaler, J.; Boggs, J.; Blake, R. A.; Magnuson, S.; Sambrone, A.; Schutten, M.; Firestein, R.; Machon, O.; Korinek, V.; Choo, E.; Diaz, D.; Merchant, M.; Polakis, P.; Holsworth, D. D.; Krauss, S.; Costa, M. A Novel Tankyrase Small-Molecule Inhibitor Suppresses APC Mutation-Driven Colorectal Tumor Growth. Cancer Res. 2013, 73, 3132-3144.

(13) Huang, S.-M. A.; Mishina, Y. M.; Liu, S.; Cheung, A.; Stegmeier, F.; Michaud, G. A.; Charlat, O.; Wiellette, E.; Zhang, Y.; Wiessner, S.; Hild, M.; Shi, X.; Wilson, C. J.; Mickanin, C.; Myer, V.; Fazal, A.; Tomlinson, R.; Serluca, F.; Shao, W.; Cheng, H.; Shultz, M.; Rau, C.; Schirle, M.; Schlegl, J.; Ghidelli, S.; Fawell, S.; Lu, C.; Curtis, D.; Kirschner, M. W.; Lengauer, C.; Finan, P. M.; Tallarico, J. A.; Bouwmeester, T.; Porter, J. A.; Bauer, A.; Cong, F. Tankyrase Inhibition Stabilizes Axin and Antagonizes Wnt Signalling. Nature 2009, 461, 614-620.

(14) Zhong, L.; Ding, Y.; Bandyopadhyay, G.; Waaler, J.; Börgeson, E.; Smith, S.; Zhang, M.; Phillips, S. A.; Mahooti, S.; Mahata, S. K.; Shao, J.; Krauss, S.; Chi, N.-W. The Parsylation Activity of Tankyrase in Adipose Tissue Modulates Systemic Glucose Metabolism in Mice. Diabetologia 2016, 59, 582-591.

(15) Schneikert, J.; Behrens, J. The Canonical Wnt Signalling Pathway and its APC Partner in Colon Cancer Development. Gut 2007, 56, 417-425.

(16) Akhmetshina, A.; Palumbo, K.; Dees, C.; Bergmann, C.; Venalis, P.; Zerr, P.; Horn, A.; Kireva, T.; Beyer, C.; Zwerina, J.; Schneider, H.; Sadowski, A.; Riener, M.-O.; MacDougald, O. A.; Distler, O.; Schett, G.; Distler, J. H. W. Activation of Canonical Wnt Signalling is Required for TGF- $\beta$-Mediated Fibrosis. Nat. Commun. 2012, 3, 735.

(17) Angelova, M.; Zwezdaryk, K.; Ferris, M.; Shan, B.; Morris, C. A.; Sullivan, D. E. Human Cytomegalovirus Infection Dysregulates the Canonical Wnt $/ \beta$-catenin Signaling Pathway. PLoS Pathog. 2012, 8, e1002959.

(18) Voronkov, A.; Holsworth, D. D.; Waaler, J.; Wilson, S. R.; Ekblad, B.; Perdreau-Dahl, H.; Dinh, H.; Drewes, G.; Hopf, C.; Morth, J. P.; Krauss, S. Structural Basis and SAR for G007-LK, a Lead Stage 1,2,4-Triazole Based Specific Tankyrase 1/2 Inhibitor. J. Med. Chem. 2013, 56, 3012-3023.

(19) Huang, H.; Guzman-Perez, A.; Acquaviva, L.; Berry, V.; Bregman, H.; Dovey, J.; Gunaydin, H.; Huang, X.; Huang, L.; Saffran, D.; Serafino, R.; Schneider, S.; Wilson, C.; DiMauro, E. F. Structure-Based Design of 2-Aminopyridine Oxazolidinones as Potent and Selective Tankyrase Inhibitors. ACS Med. Chem. Lett. 2013, 4, $1218-1223$

(20) Bregman, H.; Chakka, N.; Guzman-Perez, A.; Gunaydin, H.; Gu, Y.; Huang, X.; Berry, V.; Liu, J.; Teffera, Y.; Huang, L.; Egge, B.; Mullady, E. L.; Schneider, S.; Andrews, P. S.; Mishra, A.; Newcomb, J.; Serafino, R.; Strathdee, C. A.; Turci, S. M.; Wilson, C.; DiMauro, E. F. Discovery of Novel, Induced-Pocket Binding Oxazolidinones as 
Potent, Selective, and Orally Bioavailable Tankyrase Inhibitors. J. Med. Chem. 2013, 56, 4320-4342.

(21) Shultz, M. D.; Majumdar, D.; Chin, D. N.; Fortin, P. D.; Feng, Y.; Gould, T.; Kirby, C. A.; Stams, T.; Waters, N. J.; Shao, W. Structure-Efficiency Relationship of $[1,2,4]$ Triazol-3-ylamines as Novel Nicotinamide Isosteres that Inhibit Tankyrases. J. Med. Chem. 2013, 56, 7049-7059.

(22) Shultz, M. D.; Cheung, A. K.; Kirby, C. A.; Firestone, B.; Fan, J.; Chen, C. H.-T.; Chen, Z.; Chin, D. N.; DiPietro, L.; Fazal, A.; Feng, Y.; Fortin, P. D.; Gould, T.; Lagu, B.; Lei, H.; Lenoir, F.; Majumdar, D.; Ochala, E.; Palermo, M. G.; Pham, L.; Pu, M.; Smith, T.; Stams, T.; Tomlinson, R. C.; Touré, B. B.; Visser, M.; Wang, R. M.; Waters, N. J.; Shao, W. Identification of NVP-TNKS656: The Use of StructureEfficiency Relationships To Generate a Highly Potent, Selective, and Orally Active Tankyrase Inhibitor. J. Med. Chem. 2013, 56, 64956511.

(23) Haikarainen, T.; Koivunen, J.; Narwal, M.; Venkannagari, H.; Obaji, E.; Joensuu, P.; Pihlajaniemi, T.; Lehtio, L. Para-Substituted 2Phenyl-3,4-dihydroquinazolin-4-ones as Potent and Selective Tankyrase Inhibitors. ChemMedChem 2013, 8, 1978-1985.

(24) Haikarainen, T.; Waaler, J.; Ignatev, A.; Nkizinkiko, Y.; Venkannagari, H.; Obaji, E.; Krauss, S.; Lehtiö, L. Development and Structural Analysis of Adenosine Site Binding Tankyrase Inhibitors. Bioorg. Med. Chem. Lett. 2016, 26, 328-333.

(25) Thorsell, A.-G.; Ekblad, T.; Karlberg, T.; Löw, M.; Pinto, A. F.; Trésaugues, L.; Moche, M.; Cohen, M. S.; Schüler, H. Structural Basis for Potency and Promiscuity in Poly(ADP-ribose) Polymerase (PARP) and Tankyrase Inhibitors. J. Med. Chem. 2017, 60, 12621271.

(26) Bregman, H.; Gunaydin, H.; Gu, Y.; Schneider, S.; Wilson, C.; DiMauro, E. F.; Huang, X. Discovery of A Class of Novel Tankyrase Inhibitors that Bind to Both the Nicotinamide Pocket and The Induced Pocket. J. Med. Chem. 2013, 56, 1341-1345.

(27) Hua, Z. H.; Bregman, H.; Buchanan, J. L.; Chakka, N.; GuzmanPerez, A.; Gunaydin, H.; Huang, X.; Gu, Y.; Berry, V.; Liu, J. Z.; Teffera, Y.; Huang, L. Y.; Egge, B.; Emkey, R.; Mullady, E. L.; Schneider, S.; Andrews, P. S.; Acquaviva, L.; Dovey, J.; Mishra, A.; Newcomb, J.; Saffran, D.; Serafino, R.; Strathdee, C. A.; Turci, S. M.; Stanton, M.; Wilson, C.; DiMauro, E. F. Development of Novel Dual Binders as Potent, Selective, and Orally Bioavailable Tankyrase Inhibitors. J. Med. Chem. 2013, 56, 10003-10015.

(28) Nathubhai, A.; Haikarainen, T.; Koivunen, J.; Murthy, S.; Koumanov, F.; Lloyd, M. D.; Holman, G. D.; Pihlajaniemi, T.; Tosh, D.; Lehtiö, L.; Threadgill, M. D. Highly Potent and Isoform Selective Dual Site Binding Tankyrase/Wnt Signaling Inhibitors That Increase Cellular Glucose Uptake and Have Antiproliferative Activity. J. Med. Chem. 2017, 60, 814-820.

(29) Waaler, J.; Machon, O.; von Kries, J. P.; Wilson, S. R.; Lundenes, E.; Wedlich, D.; Gradl, D.; Paulsen, J. E.; Machonova, O.; Dembinski, J. L.; Dinh, H.; Krauss, S. Novel Synthetic Antagonists of Canonical Wnt Signaling Inhibit Colorectal Cancer Cell Growth. Cancer Res. 2011, 71, 197-205. 